\title{
CONTEMPORARY ORIENTATIONS OF CATHOLIC THOUGHT ON CHURCH AND STATE IN THE LIGHT OF HISTORY
}

\author{
JOHN COURTNEY MURRAY, S.J. \\ Woodstock College
}

$\mathrm{A}_{\text {versies as supporting the "middle position common to Catholic }}^{\text {Mong the twenty authorities cited by Bellarmine in the Contro- }}$ theologians" on the power of the Church in temporal affairs is found the name of John of Paris. ${ }^{1}$ The citation is justified in what concerns the substance of the so-called indirect power, that is, the right of the Church to intervene, as N. Jung has recently put it, "whenever a temporal affair raises a moral issue and engages the spiritual order." However, John of Paris differs considerably from Bellarmine in his explanation of the indirect power. And if it be true to say with Moulart that "the Holy See today, while emphatically maintaining the indirect power, has abandoned the explanations of Bellarmine," it would be interesting to know whether the contemporary action of the Church is being guided by ideas found in the tradition of which John of Paris was a qualified spokesman; and if so, what light this fact may throw on the contemporary state of Catholic teaching on Church-state relationships.

The work of John of Paris, De potestate regia et papali, ${ }^{4}$ has commanded the attention of leading historians of political theory. In his

${ }^{1}$ De Romano Pontifice, V, 1 (Opera Omnia, Neapoli, 1856), I, 524.

${ }^{2}$ N. Jung, Le Droit public de l'Église (Paris, 1948), p. 113.

${ }^{3}$ F. Moulart, L'Église et l'Élat (3rd ed., Paris, 1887), p. 202; cf. the article, "St. Robert Bellarmine on the Indirect Power," Theologicat Studies, IX (1948), 491-535. I suggested in this article the reason why discussion of Church-state relationships must begin with a clarification of the notion of the indirect power; these relations, especially from a dynamic or functional point of view, are immediately concretized, as it were, in the exercise of the indirect power, as conceived in various historical epochs.

-The text was recently edited, with a good analysis and study, by J. Leclercq, Jean de Paris et lecclesiologie du XIIIe siidcle (Paris, 1942). There is scant information about the life of John of Paris (Jean Quidort, as he was called). Although he was more of a theologian than a polemist, he seems to have got himself involved in a number of arguments in consequence of his critical sense. Moreover, he was very much a Frenchman, although not as much a royal partisan as is sometimes supposed. Moreover, his originality has likewise been exaggerated; as Leclercq's minute analysis makes clear, the substance of his thought was traditional, and he added to it chiefly the personal element of a synthesis (c. pp. 164, 33-37). 
study of Bellarmine's political philosophy Arnold ranks it high among the works that were "of the greatest influence on Bellarmine's views," by reason of the fact that John of Paris "developed in most logical fashion the philosophical, natural-law concept of the state and must therefore be considered most important from an historical point of view." ${ }_{5}$ The Carlyles assert that John's treatise, De potestate regia et papali, "deals more comprehensively than any other with the whole question of the Temporal Power of the Pope." McIlwain calls it "much the ablest" of all the writing that combatted the extreme claims of the papal canonists during the strife between Boniface VIII and Philip the Fair. ${ }^{7}$ Most recently, Bowle signalizes the way in which "the secular case is trenchantly argued" by John of Paris against the hierocratic theories of Giles of Rome. ${ }^{8}$ Rivière attributes to John a high historical and doctrinal significance in that he "organized into a system" a doctrine whose roots were ancient and whose tendency was to lay down a via media between extremes. ${ }^{9}$

From the time when the conflict between sacerdotium and imperium began to grow acute in the realm of facts and therefore led to contrary formulations of theory there had been theologians who refused what they considered a false option between the extremes of a complete supremacy of Church over state and a practical supremacy of state over Church. ${ }^{10}$ Their insistence was on the traditional positions as classically stated by Gelasius I, the distinction between the two powers and the primacy of the spiritual power. However, they did not completely follow Gregory VII in his understanding of this primacy as involving that political preponderance of the papal power which Gregory espoused. ${ }^{11}$ On the contrary their effort was to formulate an

F. X. Arnold, Die Staatslehre des Kardinals Bellarmin (Munich, 1934), p. 310.

${ }^{6}$ R. W. and A. J. Carlyle, History of Medieval Political Theory in the West, V (2nd ed., Edinburgh and London, 1938), 437.

${ }^{7}$ C. H. McIlwain, The Growth of Political Thought in the West (New York, 1932), p. 263.

${ }^{8} \mathrm{~J}$. Bowle, Western Political Thought (London, 1947), p. 203.

'J. Rivière, Le problème de l'Église et de l'État au temps de Philippe le Bel (Louvain, 1926), p. 281.

${ }^{10}$ Cf. Rivière, op. cit., pp. 21-23, 272-81, 300-307, for other representatives of the tendency to a via media; in his own way Dante belongs to the number (cf. ibid., 329-40).

"Gregory VII seems to have considered that the assumption of a political role by the papacy was the necessary method and technique in the conditions of his times for achieving his spiritual end, the reform of the Church. 
understanding of the primacy of the spiritual that would more clearly reveal it as a spiritual primacy, achieved by means characteristic of the spiritual and moral, not political, order, whose direct effect would be felt in the inner realm of conscience and only thence translated into the outer realm of temporal affairs. The men who wrote in this sense in the twelfth and thirteenth centuries do not seem to have been an organized school; their only common characteristics, doubtless related to their moderation, were that they were theologians, not canonists or lawyers, men of the university, not of the Curia or Court. However, it is understandable that a focus of this kind of thought was in France. And John of Paris may properly be considered its outstanding representative.

\section{THE ANCIENT CONTROVERSY AND A MODERN ONE}

There is the more reason to study his attempt to mediate between extremist positions, under fidelity to the essential data, because there is developing today under the stress of contemporary conditions a tension between extreme positions that is not without analogy to the tension that he experienced and sought to solve. John of Paris thought in the context of the conflict between the papacy and the French monarchy. The issues in their origin as well as in their scope were highly complicated. However, one may say broadly that their origin importantly lay in a political development of the first magnitude - the emergence of the national state under a king who considered himself imperator in regno suo, and who did not hesitate to assert that "the control over the temporalities of his realm belongs to the King alone and to no one else, that he recognizes no one as his superior in it, and that in things pertaining to the temporal administration of the realm he does not propose to subordinate or subject himself in any manner whatsoever to any living man."12

This political development and its asserted consequences, for which Philip the Fair assumed the spokesmanship, constituted in effect a grave challenge to what had come to be regarded as the "Catholic ideal" of religio-political organization. Philip was asserting quite a different relation between France and the empire, and between the V, 375 .

${ }^{12}$ So Philip's position was stated to the papal legates in 1297; text in Carlyle, op. cit., 
temporal affairs of his kingdom and the spiritual power of the Pope, than had been once again canonized by Boniface VIII at his confirmation of Albert of Austria as King of the Romans. Philip was challenging what men like Henry of Cremona, Giles of Rome and James of Viterbo would have called the "Catholic thesis," if they had known the famous word-the thesis that was reflected in, though not formally adopted by, the Bull Unam Sanctam. In this document Boniface VIII hurled against Philip, as Rivière well says, "the whole ideal of the Middle Ages," 13 that "system of high religious inspiration in which the ecclesiastical power, because it holds the place of God, becomes not only the guide and the ultimate judge but also the author and by consequence the responsible tutor of the civil power."'14

Against this system Philip rebelled in the name of the independence of his kingdom and the autonomy of his kingly rule. His pretensions went, of course, far beyond mere political autonomy, to a "program of religious caesarism." ${ }^{15}$ Nevertheless, for all the exaggerations in his claims and the pridefulness of his statement of them, Philip had some ground to stand on - the ground of political fact. On the other hand, Boniface VIII, in his firm personal conviction of the immutability of the medieval system (of which, it has been said, the Unam Sanctam was in reality the epitaph), mistook the factual situation. ${ }^{16}$ In point of political fact, Philip was not a feudal overlord, in vassalage to the emperor, but a sovereign in his own right and head of a nation which regarded itself as an independent political unity. Moreover, whatever the theories of the canonists, Boniface did not in fact possess the two swords, but only one. The temporal sword was indeed accountable to him for its acts insofar as they had spiritual and moral implications; but the temporal sword was not within his delegation because it was not within his possession. Consequently it was not in the hands of the prince as a mere instrument, radically subordinated to the

${ }^{13} \mathrm{Op}$. cit., p. 94 . ${ }^{14} \mathrm{Ibid}$., p. $91 .{ }^{15} \mathrm{Ibid}$., p. 98.

${ }^{16}$ The immediate guide of Boniface VIII was, of course, Giles of Rome, whose system, as Rivière says, "was conceived wholly in function of a given set of circumstances. Giles's experience was of the politico-religious organization of his time, and the suspicion never occurred to him that the maxims and practices in which the pontifical supremacy was being affirmed might not be eternal truths" (op. cit., p. 224; cf. Appendix II, "Gilles de Rome et la Bulle Unam Sanctam," pp. 394-404). 
spiritual sword, to be used ad nutum et patientiam sacerdotis. ${ }^{17}$ Boniface VIII in the name of the primacy of the spiritual diminished what Philip the Fair in the name of the autonomy of the temporal exaggerated - the legitimate exigences of the temporal order and its proper sovereignty. Boniface took his stand on libertas ecclesiastica $;^{18}$ Philip took his stand on libertas regalis. And it was basically over these two "freedoms" that the conflict raged-over their meaning, scope and exigences. The problem was their reconciliation, without damage to the necessary and legitimate content of either. Tragically, it failed of solution, perhaps not least because the canonists on the one side and the lawyers on the other failed to keep their claims within proper limits, defined by theological truth and political reality.

There is, I think, an analogy between this conflict and the one characteristic of our own times. The basis of the analogy is the fact that now as then a political development has created a situation of social fact and of political right which must be reckoned with in solving the ancient problem of the relation between the spiritual and temporal orders. The modern development is the rise of democracy-a political development of the first magnitude, the greatest since the rise of the nation-state, and greater than it. Like that of the nation-state - in fact, like any political development - this one has been ambiguous in its origins and effects, notably on the European Continent, less so in the Anglo-Saxon political tradition. Like Philip's regalism, modern democratism on the French Revolution model spoiled its substance by becoming an ism; that is, not content with being a manner of political order, it made religious pretensions and assumed absolutist tendencies. Nevertheless the substance of the development, as likewise in the case of the nation-state, has been increasingly revealed as corresponding to an intention of nature. Pius XII has cited this view with evident approval: "... in our times, in which the activity of the state is so

${ }^{17}$ In hierocratic theory the instrumentality of the temporal power with regard to the good of the Church was the consequence of its origin from the papal power.

${ }^{18}$ In the sense of Boniface VIII libertas ecclesiastica meant not only the immunity of the Church from interference in the performance of her vital functions (as in modern negative conceptions of liberty), but also the positive empowerment of the Church so to preach her doctrine and proclaim her laws as to claim the effective obedience of her subjects. 
vast and decisive, the democratic form of government appears to many as a natural demand imposed by reason itself." 19

In consequence of this political evolution there has likewise evolved a concept of libertas civilis. There can in fact be no popular share in power, no political responsibility of rulers in their elective capacity to the people, no effective right of citizens "to express their own opinion on the duties and sacrifices that are imposed on them," and "not to be constrained to obey without having been heard," no set of conditions apt "to put the citizen in a continually better position to have a personal opinion and to express it and to enforce it in a manner that will contribute to the common good"20 - there can be none of these things without those constitutional means for the vindication of rights and interests and for the direction of the political process which are known as the democratic institutions - freedom of opinion, of association, of speech, of the press. These freedoms are therefore, by political necessity, included in the democratic concept of libertas civilis; they are part of the common good; their constitutional guarantee has in fact come to be part of the very definition of the democratic state. Without them it is not in fact possible for the human person to be "the bearer, the basis, and the end of social life," ${ }^{21}$ in a manner conformed to the demands of his dignity, as these demands present themselves to reason in the present state of social evolution. Moreover, it is now judged not politically possible or just to except out of the guarantee of these freedoms the freedom of religious association and a constitutional right to the free expression of religious opinion. Such an exception is not just; for it inevitably implies some violation of that political equality which all the citizens of a state may justly claim as a basic civic right. Such an exception is not politically possible; for as Sturzo has pointed out, in a judgment confirmed by all manner of political experience, all the democratic freedoms form an organic whole. ${ }^{22}$ Each is part of a system of liberty; all are coherent. ${ }^{23}$ As

19 Christmas Radio Message, 1944, in Atti e discorsi di Pio XII, VI (Rome, 1944), 167. ${ }^{20}$ Ibid., pp. 167, $168 . \quad{ }^{21}$ Ibid., p. 167.

${ }^{2}$ L. Sturzo, Church and State (London, 1939), pp. 429, 527.

23 This solidarity of freedoms is confirmed in a curious way by contemporary Spanish apologists for restrictions on freedom of religious propaganda in Spain; so, for instance, J. Iribarren, editor of Ecclesia, argues that freedom for religious propaganda would mean in effect freedom for political propaganda injurious to the state and national unity: "Now that political extremisms are forbidden, a possible and good form of political protest, and 
political institutions all the particular freedoms rest on the same general judgment - that the system as such is rational, necessary for the common good, related to the political realization of personal dignity - whatever may be the defects in the workings of the institutions. It is not therefore possible within this system to make exceptions without endangering the political system itself. Consequently, the historically realized concept of libertas civilis has come to include "religious liberty" in a sense as ample as the concept of civil liberty itself.

It is precisely at this point that the problem of the relation of the two powers arises in its contemporary phase, in the disputes over religious liberty. As in the days of Boniface VIII there has been a clash of asserted freedoms. To the historically realized concept and political ideal of libertas civilis there has been opposed that concept and ideal of libertas ecclesiastica which was realized in the post-Reformation "confessional state," the nation-state with predominantly Catholic population, wherein Catholicism was legally recognized as "the religion of the state," and wherein it was considered "logical" as well as politically necessary that legal restrictions should be imposed on other religions, notably on their propaganda. ${ }^{24}$ This type of

a nucleus of attraction for discontented people of a certain social and intellectual category offered by their foreign masters, is Protestantism, now more of a 'protestantism' than ever. The actual campaign pitched in the religious order by strong foreign powers is one more phase of the battle, shattered on other fronts, against Spanish unity" (Ecclesia, 26 de Junio, 1948, p. 7). E. Guerrero likewise argues that religious freedom for Protestants in Spain would in effect mean that "international Jewry and Masonry would call into play all its enormous economic, diplomatic and political resources to flood Spain with waves of propaganda of all kinds," to the political ruin of Spain and the reduction of her culture "to the level of the materialist and pagan Anglo-Saxon and Masonic culture" ("El problema de la libertad religiosa," Raz6n y Fe, Noviembre, 1948, pp. 534-35). Insofar as the argument rests on a concept of national unity and national culture, it strongly suggests the horrendous visions that have at times been conjured up in the United States detailing the disastrous results of a "breach in the wall of separation of church and state." However, my point here is simply to suggest that there is general recognition of the intimate relation between freedom of religious speech and freedom of political speech, in such wise that the denial or granting of one implies in fact the denial or granting of the other. I say this without wishing to imply that these two freedoms, considered in their distinctness, could be projected on an identical basis of theory.

${ }^{24}$ Pending further discussion, I should here mention only the fact that there are important differences between the modern "confessional state" and the medieval respublica christiana. 
religio-political organization had come to be regarded as "the Catholic ideal," as an incarnation of "the Catholic thesis," as "common teaching," in much the same sense in which the "ideal" nature of the medieval system was "common teaching" in the days of Boniface VIII. It is reflected in, though not formally adopted by, nineteenthcentury papal writings in much the same way as the medieval "ideal" was reflected in Unam Sanctam. ${ }^{25}$ And it is to this special concept of libertas ecclesiastica that the democratic concept of libertas civilis issues its challenge. The challenge is serious, fraught with consequence for both state and Church. And like the quarrel between Boniface VIII and Philip the Fair, it requires a solution in principle, because, again like that quarrel, it has reached the stage of a clash of principle. It will not be solved save by a doctrinal effort such as Boniface VIII failed to make - the effort to construct a doctrinal synthesis of Church-state relations which will be at once true to permanently valid traditional principle and also universally valid within the horizons of today's factual and legitimate political development.

The complications of the problem are evident. The initial one, of course, is the historical failure in the eighteenth and nineteenth centuries to put the problem on its proper footing. Guillaume de Nogaret, Pierre Flote and Pierre Dubois, who confused the thirteenthcentury issue with their false theories of libertas regalis, had their successors in the revolutionary doctrinaires who confused the modern issue with their false theories of libertas civilis - the two sets of theorizers being similar in the additional respect that they shared a theory of state absolutism, respectively regalist and democratist, that the Church could not fail to recognize and oppose to the hilt as her enemy, as it is the enemy of human freedom. Moreover, as Philip's lawyers flung against Rome a Gallican theology of the Church, so the modern revolutionary democratists flung against the Church a rationalist concept of religion. And in the course of the ensuing theological and

${ }^{25}$ The problem of the place occupied in the teaching of Leo XIII by the confessional state on the historical model is a difficult one, not to be solved by reference to a few isolated texts; his position is too nuancee. That he approved certain of its realizations is evident -for instance, in his letter, Pergrata Nobis, to the Portuguese bishops in 1886; cf. Leonis Papae XIII Allocutiones, Epistolae, Constitutiones, II (Paris, 1887), 243. That he considered it in all its details to be the perennially necessary embodiment of a Catholic "thesis" or "ideal" is by no means evident. However, this is a separate subject for later discussion. 
philosophical disputes the politically relevant facts and rights, as they bore on Church-state relationships, were almost lost from view.

There has been, for instance, in modern times much argument back and forth, whether man has a "natural right" to profess any religion he chooses or none at all. The eighteenth-century doctrinaires put forth their affirmative claim within the context of their concept of "natural right" as the unlimited, quasi-divine attribute of the Sovereign Individual of rationalist theory, whose "huntan reason" (in the words of proposition 3 of the Syllabus) is, "apart from any regard had to God, the single judge of truth and falsity, good and evil, and a law unto itself...." ${ }^{26}$ To this pseudo-philosophical claim the Church opposed the doctrine that no man has any "natural right" (understood as a moral empowerment deriving from a duty imposed by the exigencies of objective law) to worship God in any way other than that warranted by reason and revelation. The rationalists made of their dogma a principle of religio-political organization and the premise of a regime of legal persecution of the Church such as was laid down by the French Law of Separation of 1905. In their turn Catholics likewise made of their dogma a principle of religio-political organization and the premise of the legal repression, to greater or less degree, of religious dissenters within the "confessional state." (In this exercise of "logic" the Protestant confessional states somewhat bettered the Catholic instruction.) So the issue of libertas ecclesiastica vs. libertas civilis was historically joined.

However, one cannot escape the impression that here, as in the case of Boniface and Philip, the clash of opposed historical systems has created a set of alternatives between which the Catholic-be he man of the university or man in the street-may well refuse to choose. Surely the dilemma, state confessionalism $d$ lespagnole versus state laicism $d$ la Tiers République, is no more a valid statement of alternatives today than was that which confronted John of Paris-Roman curialism versus French regalism. And the man of the university today will, I think, have the support of the man in the street in a search for a via media.

The search supposes a valid statement of the complete problem in

${ }^{20}$ Denzinger-Bannwart-Umberg, Enchiridion Symbolorum (ed. 24a, Barcelona, 1948), n. 1703. 
the modern phase of the Church-state controversy as it revolves about the concept of religious liberty as a constitutional guarantee. It is doubtful whether such a statement can be made against the European background. The experiments in absolutism of ruler-sovereignty, utterly alien to the medieval spirit, to which the Continent deviated in the fourteenth century under either pagan or Byzantine forms, threw the political order in the Continental nation-states quite off the track of rational evolution. In consequence the democratic development had to appear as a revolution; and the violence of its reaction to the irrational political order of the divine right of kings inevitably carried it over into opposite irrationalities. These in turn by the strange paradox that ineluctably accompanies reaction bore the mark of the identical original political sin, absolutism, from which they were supposed to be the redemption. The overturned throne of the king-bydivine-right was set up again to be the seat of the new divina maiestas, the Indivisible Sovereignty of the state, endowed with juridical omnipotence. The Church confronted her old enemy in a new form, and there began the wearisome struggle that filled the nineteenth century. The spiritual issues were always clear to Gregory XVI and to Pius IX; but the former Camaldulese monk had no grasp of the political issues, and the great Pio Nono, deeply spiritual of soul, volatile of temperament, found politics in general so boring that he was content to leave such affairs to the worldly hands of Antonelli. ${ }^{27}$ At all events, the result was an embroilment more complete than that which was the death of Boniface VIII. The inherent rationality of the democratic development was obscured to the view of churchmen in a fog of false ideology that pretended to justify it; and the perennial validity of the claims of the spiritual power both to exist as a power and to reach the spiritual and moral issues in the political order could not be seen by statesmen by reason of that same fog.

In view of the hopeless complication of the European scene, I think that the real issue in the controversy over religious liberty is better seen against the background of political life in the Anglo-Saxon countries. The reason is not simply that these lands saw the consummation of religious divisions. Nor is it only that in these lands constitutional provisions for religious liberty did not appear as the ${ }^{27} \mathrm{Cf}$. F. Hayward, Pie IX et son temps (Paris, 1948), pp. 174, 413. 
formal means for effecting a dechristianization of the populace - as the agency of an apostate governmental power for bringing about a national apostasy; so they were considered in Latin lands. Rather, the reason is that the Anglo-Saxon political tradition suffered only briefly the blight of absolutism. It reached England with Henry VIII's proclamation of himself as head of the Church of England in 1531 and lasted until the so-called Glorious Revolution, the whole episode being conducted under Protestant auspices, with a short (five-year) Catholic interlude. It left survivals in the form of legal disabilities against Catholics that lasted for a century and a half. But the episode was only an episode; with relative quickness the principles of government that were of medieval provenance and had been deposited in the English common law reasserted themselves. ${ }^{28}$ On the formation of the United States of America - the first state in the history of the world that was established by the uniquely revolutionary means of a formal constitutional consent-these principles received an expression that was indeed colored to some extent by eighteenth-century ideology, but not to the point of obscuring or deforming the great medieval tradition of constitutionalism that had been preserved and developed in Anglo-Saxon political society.

${ }^{28}$ So long does it take for the conclusions of historical research to reach the popular mind that it is still possible for a Protestant bishop to draw cheers in a crowded auditorium by denouncing the supposed attempt of the Catholic Church today to effect a return "to the totalitarianism of the Middle Ages." In a brief chapter F. Kern distinguishes the three principles of medieval constitutionalism: (1) the principle of the legal limitation of power (the king is bound to the law); (2) the principle of popular representation in government (the king's duty of obtaining consent to his government and legislation, as a means of controlling the king by the community's sense of justice); and (3) the principle of the political responsibility of power (the popular right of resistance to authority when it violates law); cf. Kingship and Law in the Middle Ages (Oxford, 1948), pp. 181-205. The Carlyles' monumental researches had already made clear that these principles were characteristic of medieval political civilization, and had shown too how there had been a strong beginning of the development of institutions, especially in Spain and England, for their effective operation. This development and the principles that inspired it withered with the rise of absolutism-the resurgence of the pagan idea of the monarch legibus solutus - at the Renaissance; absolutist tendencies were later strengthened by the political theories of the early Reformers, and by the whole political upheaval that followed the religious upheaval. All that is best in modern democracy is a reviviscence of what Kern calls "the eternal Middle Ages" (p. 205). It is about time that even popular orators knew the political fact that no epoch was ever more free from "totalitarianism" than the period which knew Catholic unity and Catholic "domination" at its highest. 
Actually, the American Constitution embodies a concept of the state and of government that was fashioned at the dictates of practical political sense, themselves guided by a concern for justice and liberty, and illumined in their highest underlying intuitions by a belief in God and an order of natural law. In the First Amendment the guarantee of religious freedom appears in relation, not to a rationalist theory of religion, but to a rational theory of the state. Its essential premise is the distinction of the civil and the ecclesiastical jurisdiction which the great English ecclesiastical jurists, Glanvill and Bracton, had elaborated and stamped on the common law. ${ }^{29}$ What the First Amendment fundamentally declares, as the constitutional will of the American people, is the "lay" character of the state, its non-competence in the field of religion, the restriction of its competence to the secular and temporal.

There is here a unique historical realization of the "lay" stateunique because this lay state is not laicized or laicizing, on the Continental model. This lay state does not pretend to be The Wholean absolutely autonomous, all-embracing religio-political magnitude with its own quasi-religious content-such, for instance, as the Third Republic was in the minds of the small knot of men who shaped it..$^{30}$ On the contrary, there is in the First Amendment a recognition of the primacy of the spiritual - a recognition that is again unique, in that it is a recognition of the primacy of the spiritual life of the human person, as a value supreme over any values incorporated in the state. There is too an implicit recognition that this region of man's spiritual life is the

${ }^{29}$ Madison, for instance, appeals to it in a fumbling sort of way in his famous Memorial and Remonstrance; cf. American State Papers on Freedom of Religion (Washington, 1943), pp. 84, 87. The modern political implication of the distinction is stated in the Act for Establishing Religious Freedom in Virginia: "that our civil rights have no dependence on our religious opinions."

${ }^{30}$ In this connection it is revealing to note the rejection by French political leaders of the famous distinction on which Leo XIII based the ralliement-between regimen and legislatio. Soderini says: "The Radical Deputies were unanimous in crying that the Republic was a bloc, not only a form of government but a doctrine, to be taken or left in its entirety" (Leo XIII, Italy and France, transl. by B. B. Carter, London, 1935, p. 222). He also quotes the declaration by the Radical government that "the Republic... establishes as a condition of existence... the absolute independence of civil society" (loc. cit.). This was the "doctrine" that the Church refused to accept; it enthroned the state as Hobbes's "mortal God," no less a divinity for all that it had shed royal raiment for the bureaucrat's business suit. 
source from which the state itself receives its ethical content, its moral purpose, and the higher norm that governs the operation of its political processes. In other words, the First Amendment rescues the American state from the monism which has characterized the modern laicized state. Its premise is the Christian dualist concept of man; and it recognizes that a dyarchy therefore governs the life of man and of society.

However, this dyarchy has not the form that prevailed in the Middle Ages - the dualism of auctoritas sacrata pontificum and regalis potestas (with its oscillations between caesaropapism and hierocratism). Nor is it the dyarchy constituted in the so-called confessional state of post-Reformation times-the juridically established co-partnership in society of state and Church (Catholic or Protestant - the Protestant form being the "Church-state" of Erastian tendency, and the Catholic form being the "state-Church" with boundaries of jurisdiction laid down chiefly by concordat). The terms of the dyarchy visible in the First Amendment are not state and Church (that manner of dyarchy is constitutionally excluded by the provision against "establishment of religion"), but state and human person, civis idem et christianus (to adopt Leo XIII's phrase). ${ }^{31}$ The American state does not recognize on the part of any Church the right to direct and authoritative intervention in its processes; to this extent it asserts its own autonomy as a political order. However, it does recognize in American society a "spiritual power" that stands, as it were, not only over against it but above it - the Christian conscience, whose demands are acknowledged as relevant to the political order, whose right of moral judgment on all the processes of government is likewise acknowledged, guaranteed free expression and provided with institutional channels for it. The First Amendment therefore constitutionally forbids any politico-legal bonds between the state and any Church by its prohibition of "establishment"; at the same time it constitutionally provides for relations between state and Church at a deeper, moral level by its provision for religious liberty - the immunity of conscience from governmental coercion, and the freedom of conscience to impose upon government the moral demands that are the permanent exigences of the human spirit in consequence of its obligation "to obey God rather than man."

"Immortale Dei, op, cit., II, 154. 
Finally, be it noted that the existence and workings of this unique dyarchy pivot on the concept of libertas civilis enshrined in the First Amendment. The concept is articulated-free exercise of religion, freedom of speech and of the press, freedom of assembly, freedom of petition for redress of grievances. All these freedoms make an organic whole, a consistent system. Together they insure the autonomy of the lay state; and together too they insure the primacy of the spiritual end of man, and all its exigences, over the lay state. It is this whole system of ordered liberties that "We, the People of the United States," as citizens of equal right, have judged rational and necessary "in order to form a more perfect union, establish justice, insure domestic tranquillity, provide for the common defence, promote the general welfare, and secure the blessings of liberty to ourselves and our posterity...."

I am not of course suggesting that the American state exhibits the pure embodiment of all the principles stated in the treatises de ethica sociali; no political realization is ever pure. Nevertheless, I do think it offers a political category in which the contemporary problem of religious freedom can receive its valid theoretical statement. This problem, in its correct manner of statement, is but a prolongation of the problem that was first raised in its full theoretical and practical amplitude by Philip the Fair. As Rivière remarks, "thanks to the historical conditions surrounding its advent, the problem of the two powers was, or seemed to be, conceived entirely in function of the pontifical supremacy as the Middle Ages had understood and practiced it." ${ }_{32}$ And the postulate for its solution was the concept of the pontifical plenitudo potestatis as put in practice by Gregory VII and his successors and as finally systematized by Giles of Rome - a concept that assumed in the Pope a power of political tutelage, as well as moral direction, of the political order. ${ }^{33}$ However, Philip gave the problem a different manner of statement, in terms of the autonomy of the temporal power and of the independence of the order of human life over which it reigned. Granted that his solution of the problem thus

sz Op. cil., p. 372.

${ }^{3}$ The modern counterpart of the medieval aprioristic concept of plenitudo potestatis, used as a premise for deductive argument, would be an aprioristic concept of a "perfect society," used in the same way. 
stated was outrageous and injurious, it remains true that he sharply called attention to what was a real, but had been a somewhat neglected, element in the position of the problem itself. The problem in fact is that of so stating the primacy of the spiritual -in itself, in its manner of exercise, in its consequences - as not to injure the due autonomy of the temporal power and the legitimate independence of the state. At our distance it is easy to see that the majority of medieval theoricians of the papal power quite undercut the legitimate exigences of this autonomy and independence, just as conversely Philip hopelessly overstated them. At all events, in the controversy the problem itself moved into a new and more exact manner of statement.

It is, I think, the modern manner of statement. The whole development of the doctrine of Church-state relationships has been conditioned by the sharpening of the distinction between the two orders of human life as the temporal order has progressively grown into its natural autonomy. The outset of the fourteenth century marked the acquisition by the nation-state of its autonomy; and it was in terms of the autonomy of the nation-state that the problem of the autonomy of the temporal order was posited. The very position of the problem in these terms marked in point of fact the end of papal jurisdiction over the temporal power as it had been historically understood. Theorists, and to a lesser extent the papacy itself, attempted to maintain that the nation-state stood in the same relation to the papacy as the empire; ${ }^{34}$ but the claim had no foundation in political fact, and could not therefore be made operative. Actually, the centralized national monarchy, of which the French was prototype, did not acknowledge the same dependence upon the Pope that the imperial power traditionally had recognized. And it could and did make a good case for its own autonomy. Thus did the political development of which Philip the Fair exhibited the first sharp historical consciousness make necessary a new solution of the problem of the two powers by altering profoundly the manner of its statement. The question was no longer sacerdotium and imperium but sacerdotium and regnum. A new free-

${ }^{24}$ Here was a fertile source of opposite confusions. Regarding the King of France as related to him after the fashion of the emperor, the Pope sought to control him as he controlled the emperor. Conversely, regarding himself as emperor in his own kingdom, the King of France sought the title of pugil fidei catholicae that had historically belonged to the emperor. 
dom had been achieved in fact and proclaimed as a matter of right; and no one could contest the right because the fact was incontestably juridical. It was with the new libertas regalis that the old libertas ecclesiastica had to establish proper relations. But this would require modification, not of the principle of the primacy of the spiritual but of its applications, its manner of exercise, its scope, its exigencies. Boniface VIII, prisoner as he was within the perspectives of the past, and fierce defender of a "Catholic ideal" that had in fact perished under the relentless advance effected by dynamisms of the rational political order, did not see this. And Rivière rightly says: "He would doubtless have been much surprised to be told that the clearest result of his claims was going to be the exposure of the thesis which he undertook to defend to the blows of criticism and to the implacable control of facts." ${ }_{35}$

The great modern fact of the lay democratic state, exemplified (as I suggested) in the American Constitution, has given a further nuance of development to the statement of the Church-state problem that emerged in the mighty controversy raised by Philip. The fact of democracy is indeed quite implacable in its control of the problem, given that it is "a natural demand imposed by reason itself." Again the problem is that of the legitimate demands of the autonomy of the temporal order as counterpoise to the demands of the primacy of the spiritual. This, I say, is the doctrinal problem. ${ }^{36}$ But it is posited now in terms, not of the nation-state but of the human person, who is the "bearer, the basis and the end of social life," and who as free citizen is the responsible agent of the political processes, the participant by right of human dignity in the public power whereby his temporal destiny is ruled-in a power too whose exercise is limited by a constitution that is the common act of "We, the People" (in the famous American phrase). This is indeed a further and far-reaching alteration in ${ }^{35}$ Op. cit., p. 95.

sa The polemical problem doubtless still remains-the refutation of Continental Liberalism, i.e., state secularism of an absolutizing tinge, in its theory and connected political practice; however, this is a different problem. Historically, the concept of civil liberty may have rested on rationalist premises; but it need not and should not. There is also a problem of more historical content-the defense, on whatever grounds are available, of that special system of Church-state relationships known as the "Union of Throne and Altar," or its variations, where they may still obtain. This is primarily a concrete problem, in which national contexts and traditions are important. However, the doctrinal problem is on a deeper level and is of a more positive and universal bearinge 
the statement of the ancient problem of the two powers. The problem is no longer sacerdotium and regnum but sacerdotium and civis, the civic person who, through the medium of the democratic institutions, is in a new and legitimate sense self-governing. Another new freedom has been achieved in fact and proclaimed as a matter of right. And no one can contest the fact because the right is established on rightful grounds - not on the rationalist autonomy of the omnipotent monad of the "Declaration of the Rights of Man and Citizen," but on the genuine moral autonomy in the face of the state of the "man" of whom the Declaration of Independence speaks-the man who knows himself to be a creature of God. He is the "man" whom, as Pius XII says, "the absolute order of beings and purposes reveals as an autonomous person, the subject of inviolable rights and duties, the root and the term of his own social life." ${ }^{37}$ It is with this new "ruler," armed with his democratic instruments of rule, that the Church is now confronted. It is with his new liberlas civilis that the old libertas ecclesiastica has to establish proper relations. One may expect that they will not be established without some modification, again not of the principle of the primacy of the spiritual but of its manner of exercise, applications, scope, exigencies.

I shall not pursue the subject here. The point was simply to indicate a certain analogy between the problem that confronted John of Paris at the outset of the fourteenth century and the problem that confronts the Catholic theologian today. John of Paris sought a solution through a via media. He was one of a not inconsiderable group who,

... all together, though each in his own way, preoccupied themselves with reacting against the extreme theories which would have resulted in an absorption of the state in the Church or of the Church in the state, and with affirming the normal distinction of the two domains, without however for that reason - and this is their originality - seeming to sacrifice the primacy of the spiritual. If by the first point they stood out against the absolute theoricians of papal rights, they stood close to them by the second. These patriots were independent enough to uphold the claims of the king in all that was legitimate in them. At the same time they were firm enough in their faith to safeguard the essential privileges of the papacy, and enlightened enough in their theology to return to the great Catholic tradition, without neglecting the solution of the new problems that had arisen since

${ }^{\text {"7 }}$ Christmas Radio Message, 1944, op. cit., p. 170. 
Gregory VII-in a word, to affirm the supremacy of the Church without compromising the normal independence of the state. ${ }^{38}$

The question then will be whether this via media is indeed "the great Catholic tradition," and whether therefore, if developed in eodem sensu, it may show the way to the solution of the contemporary problem, which has itself developed in the sense taken by the problem in the fourteenth century.

\section{JOHN OF PARIS}

On first reading one might gain the impression that the dominant purpose of the treatise, De potestate regia et papali, was to repudiate the prevailing theories of potestas papalis in favor of a new theory of potestas regia. The heart of the treatise would seem to be in its eleventh chapter, in which are set forth forty-two of the arguments currently proposed in favor of the curialist theory, and in the ensuing nine chapters devoted to their refutation. And even in the initial ten chapters there is implied much criticism of the theorists of pontifical power. One might then, I say, have the impression that John of Paris was one of the king's partisans. The impression needs some correction. Undoubtedly, John of Paris was concerned to refute the views of the theologians of hierocratic tendencies; and his catalogue of their arguments and his answers to them were the most elaborate in the literature of the time.

However, he was basically no partisan. His chief preoccupation was not polemic, but theological. Prominent in it therefore was the concern to rescue all that he considered true and traditional in the "Catholic ideal" as proposed by the hierocrats by incorporating it in a synthetic conception of the relations between the spiritual and temporal that would be, he considered, more in harmony with the nature of both. All his students remark his originality. However, his originality did not lie in the negative part of his critique, nor even in the substance of the position he took (which he considered to be the genuinely traditional position), but in the fullness of his argument and the resoluteness of his synthesis. And his main effort was to set forth a concept, not in the first instance of the kingly power, but of the supremacy of the spiritual power. It was a concept different from the

${ }^{28}$ Rivière, op. cit., pp. 305-306. 
one commonly held at the time; but in setting it forth his intention was not to support the pretensions of the king but to establish the position of the Pope on its genuine spiritual bases. It was in order to do this that he felt it necessary to analyze at length the autonomy of the kingly power and to refute at still greater length the theories that diminished this autonomy in consequence of a failure exactly to delimit theological principle and justly to estimate political right.

It cannot of course be said that he elaborated a theory of Churchstate relations that was complete and unexceptionable to criticism. He wrote at the outset of the fourteenth century, when certain elements of ecclesiological doctrine were not yet fixed in universal consciousness, and some of his incorrect and imprudent suggestions were later utilized by Gallican theorists. At that, the Gallican touches were accidental to his system and readily separable from its substance. ${ }^{39}$ Journet's judgment is hardly fair, that his "theological synthesis [is] too fragile to inspire confidence." 40 Rivière is more just in situating him among the thinkers who "opened the path along which modern theology has sought, if not always found, the theoretical formula of the relations which unite the two powers. Not that the doctrine of the relations between Church and state was elaborated during that epoch in all its perfection. The merit of those early pioneers is sufficiently found in the fact that they sketched its major lines and prepared for its advent." ${ }_{41}$ It would be my own judgment that the major lines of the synthesis of John of Paris are not fragile but firm.

\section{The Distinction of the Two Powers}

The first three chapters of the work indicate these major lines. The first deals with the nature and origin of the regnum; the second with the nature and origin of the sacerdotium; the third begins a comparison between them to see wherein lies the primacy of the spiritual power.

One is instantly reminded of the structure of the Gelasian doctrine

"Such, for instance, as his suggestions in regard of the relation between Pope and General Council, and on the deposition of the Pope (this latter topic was a commonplace in medieval controversy).

${ }^{40}$ C. Journet, L'Église du Verbe Incarne, I (Paris, 1941), 285, note 2.

${ }^{4}$ Op. cit., p. 307. 
contained in the famous text Duo sunt, ${ }^{42}$ that has always been considered to contain the essence of Catholic tradition. In a true sense the whole of Catholic theory and practice in the manner of Church-state relationships has taken the form of a speculative interpretation and practical application of this text. Carlyle has shown how its doctrine was controlling throughout the medieval period. ${ }^{43}$ The primacy of the spiritual had indeed been overturned in practice by the strong emperors from Otto I to Henry III in a time of ecclesiastical weakness, disorganisation and excessive immersion of prelates in the political order; and it had been challenged in theory by certain theoricians of the rex-sacerdos. However, after its reassertion by Gregory VII it was not successfully contested. Thereafter the other Gelasian principle, the duality of the powers, was to the fore.

It was never denied; even Boniface VIII vehemently repudiated the suggestion that he had contravened or ignored it.44 However, in the twelfth century there were the beginnings of a theory that attenuated its exigencies and in tendency obscured it-the so-called hierocratic (or theocratic) theory. Its essential contention was that the temporal power was from God only mediately, mediante papa. Consequently it held that the prince was simply minister sacerdotii, delegated by the Pope for the exercise of that portion of the rule of the respublica christiana which could not fittingly be in ecclesiastical hands. The temporal sword was used "manu regum et militum," but it really belonged de iure to the Pope, and hence its use was always "ad nutum et patientiam sacerdotis." 45 The radical subordination of the temporal to the spiritual power, as instrument to principal cause, was

${ }^{12}$ Text in J. B. Lo Grasso, Ecclesia et Slatus: De mutuis officits et iuribus fontes selecti (Rome, 1939), p. 45; cf. R. Hull, Medieval Theories of the Papacy (London, 1934), c. 2: "The Duo Sunt of Gelasius," pp. 13-28; Carlyle and Carlyle, op. cit., I, 184-93.

${ }^{43}$ Op. cit., IV, passim, and pp. 384-95; V, 355, 451-56.

4 See his vigorous protest against the French misinterpretation of the Bull Ausculta Fili (text in Carlyle, op. cit., V, 390-91): "For forty years we have had experience in the law, and we know that there are two powers ordained of God," etc.

is The expressions are from Unam Sanctam; they go back to St. Bernard and Hugh of St. Victor. On the celebrated two-swords argument, cf. J. Lecler, "L'argument des deux glaives," Recherches de science religieuse, XXI (1931), 299-339; XXII (1932), 280-303. There is hardly need to note that the direct-power theory was never Catholic doctrine in the proper sense, though it colored the thought even of many Popes from the middle of the thirteenth century quite up to Sixtus V. 
posited as the consequence of its origin from the papal plenitudo potestatis, within which was included all authority, spiritual and temporal.

This new theory, which was at least in tendency inconsistent with Gelasian doctrine, was widely held by canonists in the thirteenth century; the theologians, first among whom was St. Thomas, were in general more moderate. The main foundations of the theory were two. In the order of fact the foundation was the sweeping jurisdiction over the temporal order exercised by the great medieval Popes, notably Innocent III, Gregory IX and Innocent IV; the theory sought to rationalize these facts, notably under the leadership of Innocent IV writing as a canonist. In the order of ideas the foundation was the concept of a unitary social order dictated by the mystical metaphysic of Dionysius the Areopagite - that law of unity which was ever the conscious postulate of medieval thought. The two powers had to be reduced to unity in the unique supremacy of the spiritual power-a supremacy that required the temporal power to be, in the order of origin, from the spiritual power, and consequently, in the order of finality, for the spiritual power. This great law of unity, if it did not displace the dualistic conception of Gelasius, at least so overshadowed it as profoundly to modify its sense and implications. ${ }^{46}$ It is significant that for the canonists the chapter, Duo sunt, is not the primary locus communis, the pivot of all theory, that it had been, and would again be, for the theologians. In contrast, John of Paris uses it at crucial points in his exposé. And it is perhaps not too much to say that his system is in substance a newly emphatic, philosophically and theologically rigorous revaluation of the Gelasian dualism, as itself determinant of the nature and scope of the primacy of the spiritual. There is perhaps a significant revelation of viewpoint in the fact that, whereas Gregory VII had used the Duo sunt as a weapon in defense of the ecclesiastical power against the encroachments of Henry IV, John of Paris uses it in defense of the royal power against the excessive claims of the canonist-apologists of papal power.

John of Paris opens his treatise with the pregnant assertion: "It happens at times that one who wishes to avoid a certain error falls into the opposite error"; whereas actually, as examples prove, "faith

46 To the extent that the two powers were regarded as two functions in the one Church, not as two supremacies in two distinct societies in "this world," as Gelasius. 
occupies middle ground between contrary errors." ${ }_{47}$ So in the present case. The truth lies between the error of the Waldenses and that of Herod-between an excessively spiritual concept of papal power that would forbid it any manner of "dominion in temporalities," and the opposite concept "of some moderns" that would attribute to the Pope complete and universal temporal dominion in principle, in such wise that the prince would have his power from God indeed but "mediante papa"; the prince would have only the "immediate execution," and even this could rightly be assumed by the Pope in certain canonical cases. ${ }^{48}$ Of the first view John of Paris is content to say that it is "erroneous," and to leave it at that. His concern is with the second view. He supposes that the spiritual power has some manner of jurisdiction in the temporal order, and his effort is to define its origin and character. The weight of his argument goes to prove that the papal plenitudo potestatis does not of itself include any temporal power, as the canonists would have it. ${ }^{49}$ And the argument itself is derived from the distinction between the two powers, as it is established in terms both of natural law and positive divine law. With this distinction clearly laid down, he goes on to examine, in terms of its exigences, the nature and manner of exercise of the primacy of the spiritual power, and in the course of this discussion he sets forth his concept of what we now call the indirect power.

The first step therefore is a confrontation of the two powers, regnum and sacerdotium, with respect to their origin and nature.

\section{The Royal Power}

The regnum, he says, "est regimen multitudinis perfect(a)e [i.e., self-sufficient, in contrast to domestic society] ad commune bonum ordinatum ab uno." of nations." Its basis is the nature of man as "naturally a political or civil animal, as he is called in the First Book of the Politics." ${ }_{52}$ It is

${ }^{47}$ Leclercq, op. cit., p. 173, lines 1, 11. In what follows the numerical references (e.g., $175,23)$ refer to page and line in this edition.

$48174,8 \mathrm{ff}$.

49 $\mathrm{He}$ is not sharp about the distinction familiar to us between "temporal power" and "power in temporalities"; however, his subject is the latter.

${ }^{50} 176,23$; he uses the term "regnum" in different senses: the royal power itself, the scope of its use, the kingdom as a territorial entity.

51 176,38 . $\quad 52177,1$. 
a "necessary and useful" institution, for the achievement of that "whole life" not otherwise possible. ${ }^{53}$ That a particular man should be king is "through his election as king by the people, either in his own person or in his dynasty (domo)"; 54 "a man is king by the will of the people, but when he is king, it is by law of nature that he rules (ut dominetur est naturale)." 55 Moreover, since it is "by a natural instinct which is from God that men live in civil society (civiliter) and in community," ${ }_{56}$ the regnum itself is from God. The royal power "is from God and from the people consenting to, and choosing [its subject]";57 and the king has "a distinct power, proper to himself, which he has immediately from God and not from the Pope." ${ }_{58} \mathrm{He}$ is therefore "the minister of God," as St. Paul says. ${ }^{59}$ This briefly is Quidort's account of the origin of the temporal power.

He is likewise clear about its end. The end of civil society is "that good which can be achieved by nature, which is a life according to virtue." ${ }_{60}$ This life is achieved under conditions of peace, within an order of justice; and it supposes an equitable distribution of the burdens of community life and of the goods of this world (what we should call "prosperity"). The civil community therefore is temporal, not ultimate in its finality; the content of its common good is "the human things" that make up "the whole life" of man in this world. Moreover, this order of human life, which is fundamentally a moral order willed by God in His will of the natural institution that is civil society, is an order in its own right with a certain relative autonomy of its own. The "virtue" which is its object is "acquired moral virtue," which is "the true and perfect justice required for a regnum." 61 The civic life of virtue in this sense "has in itself the nature of a good (rationem boni) and is desirable for its own sake," even though it is not the ultimate good in the highest order. ${ }^{62}$

The origin of the royal power from God and the end of civil society

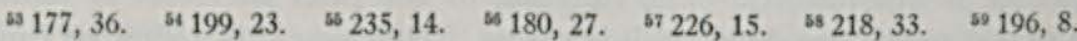

${ }^{60} 178,15$; the first part of this statement need not have a semipelagian sense (although, as is well known, the second Council of Orange was curiously not familiar to medieval writers). John of Paris recognizes the state's need of the Church, even "that justice may be observed" $(229,34)$. He asserts too that "the two swords are obliged to assist each other out of the common charity that unites all the members of the Church" $(215,26)$.

a $229,25$.

6227,18 ; he here opposes an Aristotelian metaphysic of unity (the unity of order of St. Thomas) to the prevailing Dionysian metaphysic. 
as justice, peace, and prosperity in the human temporal order determine therefore the function and competence of the king. In general, "it is the duty of the human king to direct men to this end, because it is to the human king, we say, that there has been committed the highest charge of government in human affairs." 63 True, his power extends only to "the external goods" of the temporal order.

Nevertheless, since it sometimes happens that the public peace (communem pa(cem) is disturbed by someone usurping the goods of another, and because it likewise happens at times that in their excessive love of their own goods men do not share them in the manner required by the necessities or utilities of their country, therefore the prince is set in charge of such affairs by the people, as a judge who is to decide between justice and injustice, and as the punisher of injuries, and as [the one who lays down] the measure to be followed in taking the goods of individuals for the sake of the common necessity or utility according to some just proportion. ${ }^{64}$

The prince therefore is "justice animate and the guardian of what is just." ${ }_{65}$ And it is to him that there are committed all the cases involving violation of the justice enshrined in human laws, whose observance is further necessary for civil peace. ${ }^{66}$ By his discharge of this high function in his own order the king "directs the people to God." 67

It would be easy, but hardly necessary for our purposes, to signalize the Aristotelian and Thomistic traits in this concept of civil society and its government. Moreover, to our ears the doctrine has a very modern ring. This is the kind of state we can understand and accept; for it is a "lay" state that is not, however, laicized. It acknowledges its origin from God through human nature, and within it the ruler understands himself to hold a ministry from God. However, he is minister of God inasmuch as he is minister of justice, the essential civic virtue, and therefore minister of peace, which, as John of Paris sufficiently indicates, prevails in the community when the order of justice is maintained. The function of the ruler therefore is moral, and not purely legal or administrative. However it is a limited function, confined within the limits set both by its own origin, which is from nature and from the consent of the people, and by its own finality, which remains within the horizons of the temporal order. Basically, Quidort's concept of the state is the one affirmed by Pius XI in Non
$178,22$.
44 189,24 ff.
as 225,6 .
212,34 ff.
${ }^{67} 227,31$. 
Abbiamo Bisogno, when, speaking of the role of the state in education, he asserted that the state "has duties and rights [which are] incontestable, as long as they remain within the proper competencies of the state; those competencies in their turn are clearly fixed by the finalities of the state, which are not of course simply material and corporal, but which are of themselves necessarily contained within the limits of the natural, the terrestrial, the temporal." ${ }^{8} 8$

This was not the concept of the state held either by the pontifical theologians and canonists or by the regalist lawyers of Philip the Fair. The former were thinking in the categories of "political Augustinism," wherein the civil power was a ministry, not simply of God, but of the Pope, to be exercised within "the Church" (the total religio-political entity which was christianitas) in subordination to the papal power-a ministry therefore that was specifically religious, not lay. On the other hand, Philip and his lawyers in their reaction to curialist absolutism sought, as Rivière says, to reinstate in the world "the era of Byzantine absolutism." "69 Under the impact of events their theories moved from a defense of the autonomy of the royal power, to an assertion of the king's mastery over his own national church, and thence further to the assertion of a religious mission of the king in the universal Church-a mission divinely committed to him, in virtue of which he had a power within the ecclesiastical order, superior to that of the episcopate and even of the Pope himself. The Byzantinism in this concept was a violation of theological truth; the absolutism was a rupture with the medieval political tradition. But, curiously enough, this extreme theory had common ground with its opposite extreme in

s $A A S$, XXIII (1931), 303.

"John of Paris, of course, admits the common doctrine of his time that the prince is the "secular arm" that may be invoked against heretics $(242,30)$; and he projects it on the basis common at the time, that heretics are simply fugitive members of the Church, and therefore "they may by right be compelled by the Church to return" $(235,31)$, the compulsion being actually applied "by the favor of the prince" (loc. cit.). Moreover, "the emperor" should bring into play the temporal sword, "when the Pope suggests it on account of the necessity of a spiritual good"; but the emperor is conceded a right of discretion, a judgment on the "expediency" of the move $(200,25 \mathrm{ff}$.). What seems to be in his mind here and elsewhere $(190,30 \mathrm{ff}$.) is the question of a crusade. For the rest, his thought on the mutual aid of Church and state is summed up in the traditional idea that a providential reason for the distinction of the two powers is the "fostering of mutual love and charity" among the members of the Church by "ministration to reciprocal need," since "the prince needs the priest in spiritual things, and conversely" (196, $18 \mathrm{ff}$.$) .$ 
the attribution to the king of a religious mission. Both curialists and regalists were each in their own way confusing the distinction laid down by Gelasius I between the auctoritas sacrata pontificum and the regalis potestas. And it was at this point that John of Paris struck out his via media, which was to him the way of truth, by his return to the traditional doctrine of the natural origin and end of the royal power. This doctrine founds the distinction between the two powers. It therefore endows the king with his high moral function of being iustitia animata et custos iusti; at the same time it restricts his competence to the sphere of "human affairs" over which alone he is set; and it likewise establishes the title on which he is subject to the direction of the spiritual power.

\section{The Spiritual Power}

John of Paris begins his discussion of the spiritual power from the revealed fact that "the good life" in the earthly City is not man's highest end; he is further "destined to a supernatural end which is eternal life." Moreover, the whole social order of humanly virtuous life bears a relation to this higher end. The function of leading man and society to this end belongs in the first instance to "the divine King," who is also "true Priest."70 The means to the end are the sacraments, through which man participates in the benefits of redemption. And for their dispensation the priesthood was established. Its structure is hierarchical and monarchic, and at its summit stands the Pope, the one Head, whose oneness is required for the unity of the Body.

With this much established, John of Paris immediately attacks the problem of the relation between the two powers which thus confront one another, distinct and independent in their origins, distinct too but not wholly independent in their ends. His first concern is to establish the primacy in dignity of the sacerdotal power by reason of the primacy of its end, "the enjoyment of God," to which the good life on earth, over which the royal power has charge, is itself ordained. But this raises the question that was in dispute at the time: "There are some who want to extol the preeminence of the sacerdotal dignity over the royal dignity to the extent of saying that the priesthood has

${ }^{70} 178,15$ ff. 
precedence not only in dignity, as has been said, but in causality, and that the secular power is contained in, and set up by, the sacerdotal power." "71 The question then is, "in what sense does the Pope have, or not have, the said (sécular) power?" There is no need here to follow either the order or the detail of Quidort's argument in answer. The essence of it is an appeal to tradition, which vindicates the distinction of the two powers: "And they are distinct in such a way that one is not reduced to the other, but as the spiritual (power) is immediately from God, so too is the temporal (power). Hence the imperium is from God alone.... And the Pope does not receive his sword from the emperor, nor does the emperor receive his sword from the Pope.... And the Pope does not possess both swords...."72 Moreover, John of Paris is at pains to refute the curialists' attempt to reconcile the dualist conception of the powers with a unitary conception of the Christian commonwealth by a distinction between "possession" and "executive use" (executio) of the temporal sword. This, he says, would be to make the prince minister papae, whereas St. Paul makes him minister Dei. ${ }^{73}$ Moreover, it contradicts both political fact ("there were kings in France before there were Christians") and political philosophy: "The royal power is not from the Pope either in itself or in its executive use; it is from God and from the people who elect the king." 74 Again it is to the natural-law concept of the state that Quidort appeals in the ultimate instance; he will accept no theory incompatible with it.

On such ground John of Paris rejects the contention that "the secular power is contained in" the spiritual power. Later he constructs a more positive argument to the same effect, derived from an analysis of the spiritual power itself. This argument then forms the general premise of his answers to the forty-two objections. It begins with the general definition that had been laid down at the outset, that "the priesthood is nothing else but the spiritual power granted to the ministers of the Church for the dispensation of the sacraments which contain the grace whereby we are set on the way to eternal life." 75 His concern is to show that this power is singly and solely spiritual in character; and he ${ }^{7} 0$ s this by an analysis of it into its five component powers. ${ }^{76}$ These

$\mathrm{n} 185,26 \mathrm{ff}$.

"4 199, 20 ff.
$72197,36 \mathrm{ff}$.

7s $207,37 \mathrm{ff}$.
73198,27 ff.

${ }^{76} 208,9$ ff. 
are the consecration of the sacramental matter by the power of orders; the administration of the sacraments, especially of penance-the absolution from $\sin$ in the forum of conscience by the power of the keys; the preaching of the gospel by "the authority of the apostolate"; the imposition of penalties in the external forum by "the judicial power" or coercive power; and the distribution of ecclesiastical offices and faculties by the power of jurisdiction. To these is added a sixth power, that of requiring from the faithful what is necessary for the support of the spiritual ministers of the Church.

The next step is to determine "what power in temporalities and over princes" the Church has in virtue of her essential empowerments thus described; and the answer is that "from none of them have [bishops and priests] any power directly in temporalities or any temporal jurisdiction." 77 The answer is proved by examining each power in term and concluding that each is "wholly spiritual," that is, its act directly terminates at an effect that is within the spiritual order. John of Paris holds rigorously to this principle; and in terms of it he preserves unattenuated the Gelasian dualism of the powers, in opposition to a certain monism that had lodged itself in hierocratic theory. However, his dualism does not imply a simple parallelism or coordination of the two powers. The same principle that establishes the dualism-the essential spirituality of the power of the Church-also locates the spiritual power in a position of effective primacy.

\section{The Indirect Power}

It is at this point that John of Paris introduces his concept of the manner in which this effective primacy is exercised-his concept of the so-called indirect power. It is a manner of explanation different from the one current at the time, but he evidently conceives it to be the genuinely traditional explanation, which alone to his mind does justice to the data of the problem - the independence of the political order, and the transcendence of the spiritual order; which transcendence does not indeed remove the spiritual order from all contact with the temporal order, but does determine the manner in which the direction of the temporal order by the spiritual is to be effected.

The first two powers - consecration and absolution-evidently have effects only in the spiritual order. The third power, which is magiste-

"7 211,34 . 
rial, likewise has its direct effect in the spiritual order. However, this effect itself has a prolongation: "Nevertheless by this power of teaching [bishops and priests] indirectly have a power in temporalities (indirecte possunt in temporalibus), inasmuch as they lead men to penance and the restitution of stolen property, and to the largesse of temporal goods in accord with the demands of the order of charity."78 These are temporal effects, but the power of the Church does not terminate at them directly; they are repercussions in the temporal order of an action which itself remains purely spiritual. Moreover, the action in question is authoritative, in such wise as to establish a connection between the spiritual effect and its temporal repercussion. Consequently this action is a genuine means of directing the temporal processes, but a means proper to the order in which the Church exists, the spiritual order. The Pope, says John of Paris, is "the general teacher (informator) of faith and morals." 79 This is all he is; he is not a sort of super-prince, as the hierocrats would have it. However, by the very fact that he has within his spiritual power the "iuris declaratio" his action likewise reaches into the temporal order, indirectly.

Finally, even the prince is subject to this power, inasmuch as "the prince has from the Pope and the Church his teaching about faith";80 and this teaching cannot be without effects on his princely rule, at the same time that it is no threat to his legitimate independence.

Thus the Pope does not set up the king, but each in his own way is established by God, nor does he direct the king per se, as king; he directs him per accidens, inasmuch as the king ought to be a believer. In this capacity the king is instructed by the Pope about matters of faith, not about governmental matters (in quo a papa instiluitur de fide et non de regimine). Hence the king is subject to the Pope in those matters in which the supreme power [God] has made him subject, namely, in spiritual matters. $^{81}$

And the ultimate reason is the primacy of the spiritual order and end of human life: "the earthly power is immediately from God, but it is directed to the blessed life by the spiritual power."

John of Paris considers all this so obvious that he does not delay on

${ }^{78} 212,10 \mathrm{ff}$.; note that Quidort does not say that the Church has "an indirect power," but that the Church "indirectly has a power," which is more correct. It is not to be thought that the Church has two powers, one direct, the other indirect; actually she has only one power, which is purely spiritual, but which indirectly operates temporal effects. Some Catholic theologians reject the term, "indirect power," as a misnomer.
"189, 32.
${ }^{\circ 0} 218,31$.
si $226,1 \mathrm{ff}$.
s2 $226,10$. 
it. "The whole difficulty," he says, "concerns the fourth powerthe power of judgment in the external forum." ${ }_{83}$ Here he completes his thought on the indirect power, carrying out to the end the principles he has posited. The first step is a distinction between the right of doctrinal or moral judgment and the right of imposing sanctions (auctoritas discernendi and potestas cohercendi). Moreover, as regards the right of judgment a further distinction is made. There is the right of judgment on violations of justice, human law and public peace; this right belongs exclusively to the prince. And there is the right of judgment "in spiritual cases which are called ecclesiastical." These concern the faith or law of the Church herself; and in them alone the Church is competent, just as she alone is competent in them. True, her jurisdiction in these cases entails also a jurisdiction in temporalities ratione delicti; Quidort adheres to the traditional doctrine. However, he interprets it in loyalty to his fundamental principle, already posited - that the jurisdiction of the Church is solely of the spiritual, ecclesiastical order.

To be a title of jurisdiction, he says, the delictum must be one that "is reduced to a spiritual and ecclesiastical crime," one that is judged "according to the divine law, according to which the ecclesiastical judge passes sentence." If there is question solely of a delictum civile, a transgression of human law or of the order of justice that must prevail in society for the sake of public peace and the common good, the case falls to the competence of the temporal power. It could come within the jurisdiction of the spiritual power only reductively, that is, if in the case the question should be raised, "whether this (act) be a sin or not a sin, lawful or unlawful" ; 84 this is a judgment in re morum, in the field of the Church's competence. Quidort's doctrine represents a considerable restriction of the theory of intervention ratione peccati as it was widely held at the time. ${ }^{85}$ The restriction is wholly in the logic of his adherence to the exigences of his two principles - the autonomy of the temporal order, and the spiritual character of the Church's primacy.

Moreover, he separates himself more decisively from prevailing

$8212,19 \mathrm{ff}$. si $223,9$. ff.).

${ }^{85}$ See the twenty-fourth of the curialistic arguments $(204,13)$ and the answer $(228,1$ 
views in his doctrine on the Church's coercive power-the power of sanctioning her judgments by punishments of the temporal order. The crucial case, of course, was the deposition of emperors or kings. This was a penalty of the temporal order-an alteration of the king's juridical status within the political community. The curialists held that as a matter of fact it could be inflicted directly by the Pope; and they supported the fact by the famous theory, first sketched by John of Salisbury, "Eius est auferre qui de iure conferre potest." 86 Quidort's doctrine of the origin of temporal power from the natural law and the law of nations forbade him to accept this theory. And his doctrine of the spiritual character of the Church's power, in itself and in its manner of exercise, forbade him to accept the fact. He says:

With regard to the power of correction or ecclesiastical censure let it be known that it is directly only spiritual, because it can impose in the external forum no penalty except a spiritual one, unless it be under a condition and per accidens. It is indeed the function of the ecclesiastical judge to lead men toward God and away from sin, and to correct them; however, he is to do this in the manner prescribed to him by God, that is, by separation from the sacraments and from the community of the faithful-by the sort of punishment which pertains to ecclesiastical censure. I say, "unless it be under a condition," that is, unless there be the will to repent and accept a pecuniary penance; for the ecclesiastical judge, unlike the secular judge, cannot impose corporal or pecuniary penalties for a crime committed. (He can do so) only if (the culprit) is willing to accept them; for if he is not willing to accept them, the ecclesiastical judge will seek to coerce (compellet) him by excommunication or by other spiritual penalties. This is the ultimate penalty he can inflict; beyond it he cannot go. Secondly I say, "per accidens"; for if the prince is a heretic and incorrigible and contemptuous of ecclesiastical censure, the Pope could take steps with the people, to the end that the prince be deprived of his secular dignity and deposed by the people. The Pope could do this, in a case of an ecclesiastical crime whose cognizance falls to the Pope, by excommunicating all those who should obey the prince as their lord; in such a case the people themselves would depose the prince, and the Pope would depose him per accidens. ${ }^{87}$

This is the procedure, Quidort says, in cases of ecclesiastical crime: first a warning, then excommunication, then direct spiritual action on the people, on which indirectly would follow the king's deposition. However, in the case of a political crime (in temporalibus), the procedure is different: "It is not for the Pope in the first instance to correct the king, but for the barons and peers of the realm; if they cannot

${ }^{s 0}$ Cf. Rivière, op. cil., p. 30. 87 $214,1 \mathrm{ff}$. 
or dare not do so, they can invoke the assistance of the Church; and she, called into the case by the peers in support of their right, can admonish the king and proceed against him in the aforesaid manner." 88

John of Paris therefore interprets the classic right of the Middle Ages, not in terms of a direct authority over the princely power as such, but in terms of the Church's moral jurisdiction over conscience: "It is apparent that the ecclesiastical censure in its entirety is spiritual, consisting in excommunication, suspension, interdict; beyond this the Church has no power, except indirectly and per accidens." cordance with this theory he disposes of the portentous precedent that had weighed so heavily with Hildebrand; it was, he says, the barons who deposed Childeric, and Pippin was made king "by the election of the barons, and by the authority of the Pope in the sense that the Pope passed judgment upon the doubt of the nobles; actually, the nobles could have handled the matter themselves without the assent of the Pope, given a reasonable ground to do so." ${ }_{90}$ In John's judgment therefore the throne of France had never been, and could never be, directly touched by the papal power. The case of the emperor is different: "As for the papal deposition of the emperor, I answer: it is true that (the Pope) deposes him whom he himself set up, and who holds his fief from the Pope." As a statement of the problem of Church and empire this is probably inadequate; it was precisely against the notion of the emperor as vassal of the Pope that Frederick Barbarossa revolted.

Nevertheless John of Paris was quite right in seeing that the emperor stood in a special relationship to the Pope. And actually he does not reduce it to a simple vassalage. In his answer to the classic curialist argument that the ancient imperial right of rule had been lost in consequence of the sins of the emperors, with the consequence that the ius imperii passed to the Church, which then bestowed on the Western emperors merely its exercise, John of Paris answers flatly that "it is not of divine right that the emperors should be deprived of

${ }^{38} 214,33$ ff.

${ }^{89} 216,5 \mathrm{ff}$; needless to say, this was not an original theory with John of Paris. Others before him had held it, and it was later given classic statement by Bianchi, Della potestd et della politia della Chiesa (Rome, 1745), I, lib. 1, sect. 8, n. 1, p. 78; I, lib. 2, sect. 17, n. 2, pp. 418-19; et alibi.

${ }^{20} 219,13$.

"1 221,31 . 
their imperial right on account of their sins." ${ }_{92}$ Moreover, "even granted that an emperor might be deprived of his right of rule by reason of his own fault, nonetheless no right in the empire accrues to the Pope by reason of this fault." ${ }_{93}$ And the ultimate reason is Quidort's favorite one, that denies the assumption of the curialist argument-the natural and popular origins of sovereignty. The imperial crown is not a "privilege granted by clerics; rather, it belongs to the emperor by right, by the act of the people or the army ... and by the inspiration of God, because it is from God. . . "’94

Here as elsewhere John of Paris is true to the logic of his principles; and he uses his principles to clarify historical fact, not vice versa, as in the curialist procedure, which tended to derive "eternal principles" from historical fact. ${ }^{95}$ Several times John of Paris rejects this hasty generalization from facts. So, for instance, of the deposition of Childeric he says: "It is not valid to derive arguments from such individual facts, which are at times explained by devotion to the Church or to some person, or by a will to do a favor, or by some other cause, and not by a requirement of law." ${ }_{96}$ He is indeed sensitive to the value of facts in determining juridical situations, and he has no patience with the curialist passion for the a priori deductive argument from the lex unitatis, etc. ${ }^{97}$ What he in sum demands is the control of fact by principle and of principle by fact that is so important in a matter in which the contingencies of history have played so large a part.

There are other aspects of the doctrine of John of Paris which might well claim attention. However, I shall remark briefly only two, for the bearing that they have on the manner in which the problem of Church and state presented itself to his mind. First, there is his clear realization that sacerdotium and regnum are not merely two powers, two functions, within a unitary society; rather, each has place within a distinct society. John of Paris does not think of the Church in terms of

22234,33 .

235,4 .

\% 23510.

${ }^{95} \mathrm{He}$ also rejects the allegorizing exegesis beloved of the Middle Ages with its high sense of symbolism; cf. 232, 1 (on the two swords); 235, 15 ff. (on the parable of the great supper, which had called forth the famous medieval theory of the two ages of the Church; in the first she "invited" men to come in, but in the second the "compelle intrare" operated).

* $219,17$.

97 $230,231$. 
that total religio-political entity which was so frequently covered by the term in the medieval writers and later even in Bellarmine. Rather, he posits two distinct unities, each created by its own principles and in its own order. And he keeps the unity of the Church in an order transcendent to that in which the political unity of the regnum exists. This dualism of societies is indeed reduced to unity, but not in terms of a certain absorption of political unity in religious unity, as in the theocratic system of, say, Giles of Rome. The two societies are one only in their common origin from God. And their unity remains always only a unity of order, resting on the fact that there is an order of ends in human life.

There is the temporal end, vivere secundum virtutem; and there is the eternal end, beata vita. Both are ends of the one man, and are therefore related; but as ends they are distinct; for each has a distinct good as its content. Consequently, although the whole order of temporal life has a higher finality, and therefore does not possess an absolute autonomy, nevertheless it is ordained to this higher end under preservation of its own integrity, and can lay claim to a genuine relative autonomy. Consequently too the political order and the power that rules it are not to be considered simply as means to an end. This is the social metaphysic behind the essential denial that John of Paris is constantly making - that dominion over the higher order of man's spiritual life per se contains dominion over the lower order of his temporal life. Thus he formally rejects the Dionysian metaphysic and its consequences as worked out by the hierocrats. The master of the horses is not, he says, for that reason master of their harness, even though the harness is for the horses. ${ }^{98}$ Horsemanship and harnessmaking are in two different orders of art; and the harness-maker operates according to his own rules, even though it is for the horseman that he works.

Secondly, as John of Paris has a firm concept of Church and state as two distinct societies, so he also clearly realizes that there is no univocity but only analogy between them as societies. Consequently he rejects the argument from one to the other that would proceed $a$ pari. There were, for instance, those who argued that the hierarchic and monarchic structure of the Church determined-in fact, was-the

os $234,7$. 
order of the world itself, even in the political aspects of its life; they concluded that, as the unity of the Church required that the supreme spiritual power be vested in one, so too, since the unity of the Church was the unity of the world, it required that the supreme temporal power be likewise vested in the same one. ${ }^{99}$ Moreover, there were those who argued from the divine law that established the Pope as single supreme ruler in spiritual things to a natural law that would establish the emperor as single ruler in temporal things; ${ }^{100}$ they would have the empire as the necessary pendant and completion of the Church. (This medieval fallacy has its obverse today in the thinking of those shallow Protestant theorists who argue that, as the democratic regime ought to obtain in the political order, so $a$ pari it ought to obtain as the proper regime for the Church.) John of Paris perceived the fallacy in the argument; ${ }^{101}$ a fallacy, incidentally, that had recently to be exposed and once more condemned by Pius XII. ${ }^{102}$ John of Paris knew from his political philosophy that the regimen regale et politicum was of another order, with different determinants, than the ecclesiastical order. This difference of order makes illegitimate the illation from the rightness of the structure and processes of one order to the rightness or wrongness of the structure and processes of the other.

\section{JOHN OF PARIS AND THE MODERN PROBLEMATIC}

Rivière thus summarizes his judgment on the doctrine of John of Paris: "By his essential conception of the ecclesiastical power John of

${ }^{92} 230,17 \mathrm{ff}$.

$100180,22 \mathrm{ff}$.

${ }^{101}$ At the same time he seems once to have fallen into it; from a combination of Old Testament precedent (the structure of the Jewish theocracy, with a council of elders) and Aristotelian theory with regard to the excellence of the "mixed regime" in which all would have some share in power, he suggests the conclusion that the regime of the Church would be "best" if in it "all were in some way to take part" $(237,5)$. However, this idea seems to have resulted from a misunderstanding of the text of his master, St. Thomas (Summa Theol., I-II, q. 105, a. 1).

${ }^{102}$ Discourse to the Roman Rota, Oct. 2, 1945 (Atti e discorsi di Pio XII, VII, 202). The initial theme is the transcendence of the Church to all political forms; the totalitarian or authoritarian state-forms cannot claim her as model, because their theories of public power are false; nor can the democratic state-form, because its theory of the origins of public power, although true in the political order, is irrelevant as regards the Church, which does not derive from the natural law. What the Pope may have had in mind was a flurry of argument (in the Argentine, for instance) wherein authoritarian regimes were defended on grounds that they resembled the Church - a contention false in fact as well as fallacious as an argument. 
Paris joins himself to the purest tradition of the Middle Ages, since he authorizes its intervention in the political sphere. But at the same time he shows himself entirely modern by the manner in which he understands this function of the spiritual power, and by his reduction of it to the exercise of a spiritual power." ${ }^{103}$ The judgment is, I think, just. Two questions therefore arise. First, is the contemporary doctrine and practice of the Church orientated in the sense of the concept of the indirect power represented in the medieval tradition by John of Paris? Secondly, if so, what may one derive in the way of principles and practical lines of action from this orientation, toward the solution of the problem stated at the outset of this articlethe freedom of the Church in its relation to the freedoms of the citizen? As I said, the concept of the indirect power is pivotal in this whole matter.

The first question must, I think, have an affirmative answer. P. Lecler, whose competence in the history of the question is of a high order, says: "This formula for the indirect power is not only a happy one, because it sets in relief the purely religious character of pontifical authority; it likewise admirably characterizes the action of the papacy in modern times." 104 The same view is stated by R. M. Schultes: "The indirect power states a truth in its assertion that the Church claims in regard of the faithful an indirect power even over material things; however, it seems unwarranted to say that this power is a power over the state."105 And P. de Lubac has described the indirect power along the same lines; ${ }^{106}$ so too Moulart. ${ }^{107}$

The remote and traditional premise operative here was stated by Pius XII with his wontedly warm eloquence. Speaking of the Church's contribution to the development of the equality of man, even in the political order, especially in regard of the surmounting of national divisions, he says that the Church makes this contribution

... by penetrating into the deepest intimacies of the human being and by placing it at the center of the whole social order. Now this human being is not the

${ }^{103}$ Op. cit., p. 297.

${ }^{104} \mathrm{~J}$. Lecler, L'Église et la souverainete de l'État (Paris, 1946), p. 108.

105 R. M. Schultes, De Ecclesia (Paris, 1931), pp. 138-39.

${ }^{100} \mathrm{H}$. de Lubac, "Le pouvoir de l'Église en matière temporelle," Revue des sciences religieuses, XII (1932), pp. 32-54.

${ }^{107}$ F. J. Moulart, op. cit., pp. $211 \mathrm{ff}$. 
abstract man, nor man considered only in the order of pure nature, but the complete man as he is in the eyes of God, his Creator and Redeemer-man in his concrete and historical reality, which can never be lost sight of without compromising the normal order of human living together. The Church knows this and acts accordingly. It may be that in certain places and at certain times one or other culture (civilta), one or other ethnic group or social class have more than others made their influence felt upon the Church; nevertheless this does not mean that she is enfeoffed to any of them, or that she becomes, as it were, petrified in a given moment of history and closes herself to all further progress. On the contrary, bent as she is in constant attention over man, listening to all the beatings of his heart, she knows all its riches, and is aware of all its aspirations with that clarity and keenness of intuition which can come only from the doctrine of Christ and from the supernatural warmth of a divine charity. So in her progress the Church follows without pause or stoppage the providential path of history and circumstances. This is the profound meaning of her vital law of continual adaptation, which some, because they cannot rise to the height of this magnificent conception, have interpreted and presented as 'opportunism.' ${ }^{108}$

Three ideas are here: the whole man at the center of the social order; the idea of man and society as subject to the law of history, which is the law of growth and progress - the gradual explicitation of the virtualities of human nature as grace calls them forth; the Church as herself obedient, in her dealings with man and society, to this law of growth, which brings into being continually new orders. This same global intuition was central too with Pius XI-the idea that the institutions of human life are in a continual state of dissolution and new synthesis, moving always, under whatever aberrations into error and sin, in a fundamentally rational direction towards an order of social life of which the human person would be ever more perfectly, at least in aspiration, the dynamic center and the end.109 Central too with Pius XI was the idea that the action of the Church must take account of, and harmonize itself with, the historical moment in all that is rational in it.

This "vital law of continual adaptation"- not indeed to the surface movements, nor to the currents of error, but to the deeper exigences of the historical situation as they manifest genuinely human needs or 122).

${ }^{108}$ Allocution to the New Cardinals, Feb. 21, 1946 (Atti e discorsi di Pio XII, VIII,

${ }^{109}$ See, as a particularly striking text, his discourse of May 16, 1926, in L'Action Catholique, Traduction des documents pontificaux, 1922-1933 (Paris, 1934), pp. 108-13. 
mark genuinely human progress-is essentially relevant to the Church's doctrine on relations of Church and state. In the concept and reality of the "state" there have been profound historical changes and ever new realizations; and insofar as they merit the title of rationality they command changes and new realizations in the matter of the state's relation to the Church. My point here is that history and experience have brought the Church to ever more perfect respect for the autonomy of the state (as a form of respect for an essential element in the "whole man") and consequently to ever more purely spiritual assertions of her power in the temporal order. Moreover, in proportion as these assertions of a power have become more spiritual, they have become more universal and searching, reaching all the institutions of human life, to conform them in their idea and operation to the exigences of the Christian conscience. With seeming paradox, the withdrawal of the Church from a certain identification with the state in the medieval respublica and (in a different way) with the confessional state has not meant a withdrawal from society, but rather a more profound immanence, so to speak, in society, as the spiritual principle of its direction to both the temporal and the eternal ends of the human person.

This vital, not opportunistic, adaptation to what is rational in modern political development-I mean the autonomous and rationally lay state - has not indeed been accomplished in an instant. As I said, the conflict-situation created by the revolutionary emergence of the secularist state with omnipotent sovereignty has delayed and complicated the adaptation. However, there has been a resignation by the Church of the right of political tutelage over the temporal order that was claimed and exercised in the medieval respublica christiana and (after a different fashion) in the confessional state of the Reformation and post-Reformation era. ${ }^{110}$ Correlatively, there has been the assumption of a purely spiritual function and right-no less a ius divinum, no less authoritative, but now exercised in a manner more proper to the order of the Church's being, which is transcendent to the political order and by that very fact immanent in it in a way utterly respectful of its autonomy, as grace is immanent in, and transcendent

${ }^{n 0}$ Actually, the confessional state has been more prominently characterized by the state's quasi-spiritual tutelage of the Church, as in the Gallican and Josephinist realizations, or in the political messianism of Philip II of Spain. 
to, nature. The assertion of this right and role is found in the wellknown letter of Cardinal Antonelli to the French government on March 19, 1870 - a letter, it may be noted, which could hardly have been written in the sixteenth, or seventeenth or eighteenth, centuries:

(The Church) has received from God the sublime mission of directing men, both individually and in their social life, to a supernatural end. She has therefore received the authority and the duty to judge the morality and the justice of all acts, either internal or external, in regard of their conformity with the natural and divine law. No act, of course, whether it be commanded by a supreme power or freely posited by an individual, can be exempt from this character of morality and justice. Consequently, it comes about that the judgment of the Church, though it directly bears only on the morality of acts, indirectly reaches all the affairs with which this morality is associated. ${ }^{\mathrm{II}}$

This is indeed the posse indirecte in the traditional sense that we saw developed in John of Paris; it is not exactly Bellarmine - that is, it is Bellarmine only in the underlying substance of his thought, not in his systematization or in his orientations, which were, as I have elsewhere suggested, ${ }^{112}$ retrograde - directed backward to the factual and juridical situation of the Middle Ages. The orientation contained in Antonelli's statement has been rendered increasingly clear and firm by all that has been said and done by the Church since that date. It stands out in the work of Leo XIII, even though it is not developed in all its implications. Leo XIII, it is true, never cast up a formal theory of the indirect power; the term does not occur in the Leonine corpus. We are therefore left to gather his mind from the ensemble of his doctrine. However, I think it will be agreed that only the Antonelli concept will harmonize with what is the core of his doctrine-I mean his restatement of the Gelasian position in its full rigor, under no attenuations. The classic text runs:

God has apportioned the charge of the human race between two powers, the ecclesiastical and the civil, one set over divine things, the other over human things. Each is supreme in its own order; each has marked out for it by its own nature and immediate origin certain limits within which it is contained. Consequently, each has, as it were, a certain sphere with fixed boundaries; and each in its own sphere acts by native right. ${ }^{113}$

iu The Italian text is in Moulart, op. cit., p. 225.

${ }^{12}$ Cf. Theological Studies, IX (1948), 502 ff.

${ }^{113}$ Immortale Dei, Leonis Papae XIII Alloculiones, etc., II, 152; other classic state- 
The dyarchy here described is not exactly that of Boniface VIII, for all that Boniface likewise held the dualism of powers. The premises, perspectives and accent are different. Leo XIII proceeds from a fully developed doctrine of the natural-law state as a perfect society in its own right, and he consequently lets a firm accent fall on the autonomy of the state. Moreover, his perspectives are naturally those of a dualism of societies and not merely of powers; they are identically those of John of Paris, derived and developed from their common master, St. Thomas Aquinas. And, like John of Paris, Leo XIII makes clear that the "orderly relationship" (ordinata colligatio) between the two powers, that it may be orderly, requires full respect for the nature of both; its norms are not derived from a unilateral consideration of the papal plenitudo potestatis, as Quidort's adversaries would have had it. "The requirements and the limitations of this relationship (qualis et quanta ea sit) cannot otherwise be determined save by reference, as We said, to the nature of both of the powers, under consideration of the excellence and nobility of their respective finalities...."114 From this consideration of finalities there follows the primacy of the spiritual power. And the supreme requirement of the primacy of the spiritual is that the "power and judgment of the Church" should extend to "whatever in human affairs is in any way sacred, whatever pertains to the salvation of souls or the worship of God, whether a particular thing be such by nature, or understood to be such by reason of the end to which it is related." 115 This, I take it, is the pure essence of Catholic tradition: the spiritual power has for its single object the "quoquo modo sacrum," and it can touch nothing else. However, this reach to the sacred has its consequences in the order of human affairs of which the state is the political form. These consequences must follow, because the demands of the sacred have primacy over any claims of the temporal. And in this precisely consists the primacy of the spiritual power, that it reaches what has the primacy in all human affairs - the element that is sacred because it bears on the relationship of man to God and to his own supernatural destiny.

Leo XIII does not go on to the further problem inherent in the

ments are in Nobilissima Gallorum Gens, ibid., pp. 47-48; Arcanum, ibid., I, 137-38; Libertas, ibid., III, 108 ; etc.

114 Immortale Dei, op. cit., p. 152. ${ }^{115}$ Ibid., p. 153. 
primacy of the spiritual - the perennial problem of how this primacy may be insured, that is, how the spiritual judgment of the Church, after whose pronouncement (as John of Paris said) the Church can do no more, may achieve in actual fact its juridically necessary indirect prolongations in the shaping of human actions and institutions in the temporal order. Leo XIII's own dominant preoccupation was with the distinction of Church and state; with him the Gelasian formula again becomes a weapon of defense against state encroachments in the religious sphere, this time by the laicized state with its pretension of being the One Power, juridically omnipotent and omnicompetent. Correlatively, his preoccupation was with the elaboration of the concept of the res mixta - that res humana which has in it a res sacra. These "mixed matters" relate to the jurisdictions of both state and Church; and Leo XIII is concerned to vindicate the Church's competence in regard of the sacred element in them, against its denial by the secularist state. Chiefly in view, of course, was the family-the institutions of marriage and education. And here the Pope asserted the exclusive power of the Church to touch the sacred element in them - the moral and sacramental aspects of the marriage contract, the baptized soul of the child, the natural and Christian relationship of child to parent. The other, simply human and temporal aspects of these matters fell to the jurisdiction of the state.

For the rest, he insisted on the ready possibility and need of concordia, harmony (his favorite word) between the two powers in these matters of common jurisdiction - a harmony based in the first instance on friendly recognition of distinct spheres of right. Actually, there was at the time not concord but clash in these areas, in the lands of the Revolution where the doctrine of the Revolution prevailed - the absolute juridical independence of the state. As Sturzo has pointed out, ${ }^{116}$ clash in these "mixed" areas is inevitable where the state is laicized, secularist - where it claims to possess a full doctrine of its own as to what marriage and education are, the one a simple civil contract, the other a means of training children for the state (the idea of the finality of education that was introduced by Napoleon and added to the notion of education by the state). What Leo XIII was in effect saying (and he was always talking in the first instance to France and Italy)

${ }^{116}$ L. Sturzo, Church and State, pp. 386, 429, 549. 
was that the state, as the political and legal order of a Christian society (these societies still considered themselves and were in large part Christian), ought to be an order whose legislation would be in harmony with the exigences of the Christian conscience of its citizens, as these exigences are defined by the Church whose teaching and laws were recognized by these citizens as binding in conscience. In a word, Leo XIII was asserting the Gelasian dyarchy, against the "monarchy" of Revolutionary political theory and practice. Of course, the notion that shocked the "democratic emperors" of the Third Republic and the Risorgimento and the partido liberal, as it had shocked the Emperor Anastasius when Gelasius uttered it, was the notion that the spiritual component of the dyarchy also ruled this world ("quibus principaliter regitur hic mundus"). They were not troubled by the Church's activities as concerned with the next world, since they did not believe there was one. The Church "in the sacristy," as the Liberal watchword had it, was of no concern to them. However, when the spiritual power insisted on having consequences in this world, on the institutions -political, legal, social, economic - of the temporal, order there was a clash.

Leo XIII solved the clash in principle by his newly clear assertion of the Gelasian thesis; and he surely led the Church far along what Pius XII called "the providential path of history and circumstances" by his definitive establishment of the principle that the Church's action in the temporal order is purely spiritual. However, there remained, as I have said, a further problem, a further step to be taken in obedience to the "vital law of continual adaptation." This question does not concern the substance of the right of the Church to judge and-in the medieval terms - to direct and correct all human affairs under their religious and moral aspects. The question concerns rather the manner of exercise of this right. More exactly, the question is, who shall be the immediately responsible agent of this direction and correction? Who shall be the executor, so to speak, of the Church's moral judgment? This has always been the ultimately crucial question. It has always been posed in function of the autonomy of the temporal order. And its answer has always given an ultimate nuance of meaning to the concept of the indirect power. The question arose in medieval times in connection with the classic exercise of the Church's power in the temporal order, the deposition of kings. Who deposes the king in actual and 
political fact - the Pope himself directly (as many canonists said) or the people acting with a conscience informed by the Pope (as another school of thought, including John of Paris, maintained)? The division of opinion rested ultimately on varying judgments with regard to the autonomy of the temporal order.

The problem arises today on a much wider scale, and it is necessarily posited in terms of the democratic development-the more complete institutionalization of the medieval political principles to which I have already referred. If with Pius XII one regards this development as the operation of a rational human dynamism and its term as "a demand of reason itself," as this demand is made manifest through the medium of historical circumstance, one confronts the old problem in a new form. Now the autonomy of the temporal order requires that its spiritual direction and correction be accomplished from within the temporal order itself, through the agency of its own institutions, and not from without-not therefore by the efficiency of the Church as such; for the Church as such stands outside the political order, transcendent to it.

In a sense, this requirement is not new. In olden days the Church directed the processes of the temporal order through her action on the conscience of the king, who was a political institution-in fact, the cardinal political institution, unique and almost single as an influence on the shape of the temporal order. However, in another sense the requirement is new; for in the modern situation, in which democratic government is recognized as a rational postulate, the institutions for the direction of the temporal processes are manifold and many-headedthe people (in Pius XII's sense of "people" as opposed to "the masses," who are simply passive instruments of a governmental clique) and popular institutions of rule. This is the situation to which Cardinal Manning referred in his famous utterance that, as reinforced by Cardinal Gibbons' repetition of it, made such an impression on Leo XIII: "A new task is before us. The Church has no longer to deal with Parliaments and princes, but with the masses and with the people. Whether we will or no, this is our work; we need a new spirit and a new law of life." "11 It is to this situation that the Church's "vital law of continual adaptation" must be applied.

And the application, I should insist, is not properly called expediency, p. 174.

${ }^{17}$ Cf. E. Soderini, The Pontificate of Leo XIII, transl. by B. B. Carter (London, 1934), 
any more than it was expediency when the Pope ceased to consider the kings of Europe as papal vassals. On the other hand, the adaptation is simply adaptation - the Church's conformation of her thought and conduct to the juridical exigences created by a situation of political fact in whose genesis a rational dynamism is at work. There can be no question of the Church identifying herself with democracy - either as an idea or in any of its national realizations. The political thought that has its home in the Church has traditionally, by reason of its Aristotelian roots, recognized as a political ideal the regime in which "all should have some share in rule." However, the transcendence of the Church forbids her enfeoffment to any political regime, even an ideal one, at the same time that her immanence in the world requires a vital adaptation to any political regime that is rational.

It is a question whether Leo XIII fully realized the modern problematic in regard of the manner of exercise of the indirect power. Nevertheless, I consider that by some manner of genius he put forth the principle of solution. It is contained in the special twist, so to speak, that he gave to the Gelasian doctrine. Consistently he posits as the root of the necessity of an "orderly relation" between the two powers the fact that "utriusque imperium est in eosdem," the rule of both is over the same one man. ${ }^{118}$ If therefore there is conflict and not haimony between them, the conflict is felt in the depths of the personal conscience, which knows itself to be obligated to both of the powers which are from God. Their harmony therefore is required by the unity and integrity of the human personality. The whole Gelasian doctrine is thus made to grow, from the standpoint of the finality of the dyarchy, out of the essential datum, "civis idem et christianus," the same one man who is citizen and also a Christian.

This sets the Gelasian doctrine in genuinely modern perspectives, which are not those of medieval times. In the medieval universe of discourse the root of the matter was not the unity of the human person, citizen and Christian, but rather the unity of the social body which was both Church and state, the respublica christiana, whose unity required the subordination of regmum to sacerdotium because it was an inferior

11s Immortale Dei, op. cit., II, 152; Libertas, op. cit., III, 108. The same phrase occurs in these two cardinal loci; the idea often occurs elsewhere.

"1m Immortale Dei, op. cit., II, 154. 
function within the one body, instrumental to the good of the body, which was identically the good of the Church. The medieval starting point was the Church, and it set the doctrine of the two powers in characteristic social perspectives. Their "union" was a requirement of social unity. These perspectives and their consequences were carried over into the so-called confessional state with its "Union of Throne and Altar." Its predominant finality was likewise social unity, now conceived as national unity. It is obvious, for instance, how in contemporary Spain, where the Union of Throne and Altar still exists in a special form, the problem of Church-state relationships is conceived in function of the problem of national unity.

However, the Leonine starting point is not the Church nor are its perspectives social. Its starting point is the dualism within the human person, who is both child of God, member of the Church, and also member of the human community, citizen of a state - endowed in each capacity with a set of rights, which are of different origin but which must be organized into an organic whole. And the principle of organization is the primacy of the spiritual aspect of his nature, which implies the fundamental right to have the two powers to which he is subject in harmony with each other. The finality of this harmony is not a social unity but a personal unity - the integrity of the human personality. It is only by preservation of this integrity that man is truly "free," empowered to be in fullness what he is - citizen and Christian. This freedom is a positive empowerment-the full faculty of obeying the law which he knows to have the primacy (the law of Christ as mediated by the Church), under due obedience to the other law to which he is also subject, the human law of the state. Unless these two obediences are in harmony, there is no freedom.

My point is that this Leonine restatement of the Gelasian doctrine opens in principle the way to the solution of the ancient problem in its modern position - the manner of exercise of the indirect power, the manner of maintaining the primacy of the spiritual under respect for the autonomy of the temporal. Leo XIII was in advance of Pius XII in placing "the whole man in his concrete and historical reality at the center of the whole social order" in its two components, Church and state, whose dualism corresponds to the dualism in man himself and whose orderly relationship is the exigence of the unity of human 
personality. Between the essence of Immortale Dei and the essence of the 1944 Christmas Radio Message there is, to use the famous antithesis of Vincent of Lérins, "profectus fidei, non permutatio." ${ }_{120}$ Taken together and in their relationship, the two doctrines-the Leonine concept of Gelasianism and the Pian concept of a juridical democracycontribute to one effect, which is the establishment in principle of what the effective terms of the contemporary dyarchy really are. In the developed conditions of modern political society they are not the medieval sacerdotium and imperium, nor yet the Throne and Altar of the confessional state. They are sacerdotium and civis idem et christianus.

Leo XIII took the first step in thus defining the dyarchy by defining its finality - the unity of human personality. Moreover, in saying that the human person and his integrity as citizen and Christian was the end and object of the harmony between the two powers, Church and state, Leo XIII was implicitly saying that the human person by his action as Christian and citizen ought to be the instrument and agent of establishing this harmony in actual fact. ${ }^{121}$ Responsibility for the harmony rests on its beneficiary. Pius XII simply completed the progress by making explicit what had been implicit; he took the Leonine phrase that expresses the root of the matter, and developed the concept of civis. The citizen, he says, who is "a human person, the subject of inviolable rights and duties, and the root and end of social life," is therefore not "a passive element" under the processes of society but their active agent, through the exercise of his rights as citizen. Through them he has a share in the public power and therefore a responsibility to see that the processes of government, and of society in general, tend to their proper end, which is the freedom of "the whole man in his concrete and historical realization." This freedom, as I said, supposes the harmony of human obediences, which in turn supposes the harmony of the two powers that require obedience. Of this harmony therefore the human person is the responsible artisan, through the exercise of his civic rights under the guidance of his Christian conscience.

${ }^{120}$ Commonitorium, 23, Rouët de Journel, Enchiridion Patristicum (ed. 6a, Freiburg i. Breisgau, 1929), n. 2174.

12 The whole idea of the ralliement had the same implication-in itself, if not in some of the interpretations given of it. 
Thus in terms of recognized principle the contemporary dyarchy is constituted. The Church no longer, as in medieval times or in the classic confessional states, directly confronts "the temporal power" in concentrated, centralized form, in the person of the prince, who was "the government" and indeed "the state," in the sense that he wielded or delegated at his discretion the full power of the state (subject, of course, in medieval theory to the limitations of law and private right). Modern political development has operated a dispersion, as it were, of the temporal power by adding the principle of the political responsibility of government, institutionalized in the system of free elections and the other civic freedoms, to the ancient principle of the legal limitations of government, itself newly institutionalized in modern forms of constitutionalism. Consequently, what the Church immediately confronts is not the temporal power in the sense of "the government," or the state in the sense of the constitutional and legal order of society, but rather the citizen, armed with all the institutions of popular rule. To him government is responsible, and he is himself responsible as well for the actions of government as for the order of the state. (It is striking, for instance, to see the recognition of this situation of political right in Pius XII's encyclical on the Holy Land, April 15, 1949.) This citizen, and the institutions through which he shares in rule, are possessed of a genuine autonomy. It is only through him and through them that the Church can reach the temporal order (as indeed the Pope could only reach the empire through the emperor). Standing thus in the middle, so to speak (where Leo XIII put him), the citizen looks two ways. As Christian, he looks, as it were, behind him to the Church as the "general teacher (informator) of faith and morals," to use the phrase of John of Paris; as citizen, he looks before him to the state, to the whole order of human life in its temporal aspects. The action of the Church on him terminates at conscience, forming it to a sense of its Christian duties in all their range and implications for temporal life. The Christian then as citizen, in the full panoply of his democratic rights, prolongs, as it were, this action of the Church into the temporal order, in all the matters in which Christian doctrine and law has implications for the life and law and government of society. First of all, it is through the freedom of the citizen (in the modern sense) that the freedom of the Church (in the 
medieval sense) is effectively assured-her right to exercise her spiritual sovereignty over her subjects and to reach those elements of human affairs which are "quoquo modo sacrum." 122 Secondly, it is through the freedom of the citizen that the freedom of the City itself is effectively assured - that freedom which consists in the establishment and dynamic maintenance of an order of justice and charity. In these perspectives, which are set by the full development, through theological reflection and political experience, of the Gelasian doctrine, the whole system pivots on the principle of freedom. There is first the free obedience of the Christian conscience to the magisterial and jurisdictional authority of the Church; there is secondly the free participation of the citizen, as a Christian, in the institutions whereby all the processes of temporal life are directed to their proper ends.

This, I take it, is the Catholic thesis in its application to democratic society. Its essence is a concrete conception of the ancient dyarchy to which the Church has come, following "the providential path of history and circumstances." I have illustrated this conception only as it emerges from the doctrine of Leo XIII and Pius XII. There is however a resounding confirmation of it to be found in the epoch-making doctrinal and pastoral work of Pius XI-I mean his elaboration of the concept of Catholic Action, which has been called "the modern form of relations between Church and state." However, I can only refer to this subject, without pursuing it. ${ }^{123}$

in Moreover, theoretically, and apart from special problems of historic right, it may be said that the fundamental right of the Church-the right to recognition of her unique juridical personality - claims a place in the legal order, which is the state, only through the citizens; that is, the Church is a reality for the state because she is a reality for its citizens -a reality in a higher order, in which the state as such has no competence. The state may not undertake to give a juridical definition of the Church; the Church defines herself, and it is for the state to accept this definition inasmuch as it is the definition accepted by its citizens. So, by analogy, it is not for the state to define what the human person is, in its fundamental rights and freedoms; the human person defines itself, and the state accepts this definition. Here was the core of the quarrel, for instance, between the Church and the Third Republic over the Law of Separation of 1905. This law presumed to define the Church as a simple association culluelle, a corporation of private right, which the state, by reason of its juridical omnipotence, was entitled to charter, set on a par with other such corporations, and minutely regulate (as it did in the forty-four articles of the Law). The Church cannot admit that any such right to assign her a juridical status within the state lies within the competence of the state.

12 Cf. H. Carpay, L'Action Catholique (Paris, 1948) for a good statement of the function of Catholic Action toward the solution of the ancient problem of the relations between spiritual and temporal. 
My conclusion at this point should be obvious. In the first part of this essay I sketched the contemporary problematic in the matter of Church-state relationships and illustrated it by the example of the American Constitution and the political system it sets up. My point then was the sheer matter of fact that in the native structure of the American system the citizen-of-religious-conscience is placed in the mediating position between Church and state. The Church is free to form the consciences of her members; and they as citizens are free to conform the life of the City to the demands of their consciences. Both freedoms are part of an organic system of freedom. And the system itself, as a system, rests on the collective judgment of the people that this whole system is for the common good, and that no element of it may be tampered with without damage to the whole.

With this point of fact made, I went on to analyze the Church-state problematic as it has emerged in the thinking of the Church under the operation of the "providential law of history and circumstances." For all its length, the analysis was much too brief. However, three things are clear. The first is the clarification of the concept of the indirect power, as being a purely spiritual power that indirectly, by repercussion, is productive of effects in the temporal order; with this has also come a more sharply defined recognition of the autonomy of the temporal order and its processes. Secondly, there has been a new accent put on the finality of the Catholic thesis stated by Gelasius I; the orderly relationship of Church and state has always in view the inner unity and integral freedom of the human personality. Consequently, as the human person is the end of this relationship, so he is the immediate agent responsible for seeing that it is orderly. Thirdly, there has been a somewhat parallel development in political ideas: as the human person is the end of the state, so he is the participating agent in the processes of state, responsible for an order of justice and charity.

The net result of the whole development has been the resolution of the ancient dyarchy into a new, concrete, operative form - on the one hand is the Church, in the fullness of her spiritual liberty; on the other is the citizen-Christian, in the fullness of his civil liberty. It is in terms of this dyarchy that, in Gelasius' words, "this world is authoritatively ruled," now that it has reached conditions of political maturity. No doubt laicism had much to do with this development. As Sturzo says: 
"It took the experience of laicism to bring out the moral character of the relations between Church and State and to show how sociologically the dyarchy Church-State has its roots set at a deeper level than that of a legal co-partnership in society." 124 I would add that this sociological discovery has resulted in doctrinal formulations, that are not opportunistic concessions to hard circumstance but a form of obedience to the vital law of adaptation to a human progress that for all its aberrations has been fundamentally rational. In a curious sort of way, we have now come back to "the eternal Middle Ages," after the long parenthesis initiated by the fourteenth-century rise of state absolutism and the modern idea of sovereignty. I mean that the relationship of Church and state now assumes more the form of the medieval union coutumière, but in a newly institutionalized form, that situates the essential dynamic relationship at a level that permits a fuller achievement of its finality.

My conclusion then is that the Church-state problematic, as it has emerged in the thinking of the Church, presents certain striking similarities to the problematic envisaged in the American Constitution (which I used as a sort of laboratory example of the modern political category - the state that is lay in finality and function, that situates its competence within the sphere of "the natural, terrestrial, temporal," in Pius XI's words, but that is not-at least not in theory-laicized, secularist and secularizing, animated by the doctrine that the natural, terrestrial and temporal are All That Is; for it recognizes that there is a "spiritual power" in society that must be free, through an ordered system of civil liberties, indirectly to achieve the due temporal incarnation of the spiritual).

This of course does not mean a political canonization of the American state, which, like any political realization, labors under ambiguities and defects. Still less does it mean that the American state receives a sort of religious canonization by the Church. However, it does mean that the statement of the contemporary problem itself, as conceived by modern political society in terms of political principle and fact, is substantially the same statement of the problem that is now accepted by the Church, in terms of an organic development of her ancient Gelasian doctrine. This may seem like a very modest conclusion, of no great import. Actually, however, one will see that it is enormously wO Op. cil., p. 548. 
important, if one simply refers to the controversy between Boniface VIII and Philip the Fair. The trouble then was that neither side had really grasped the full scope of the problematic, as it had altered from its former position under the impact of the new political developmentthe rise of the nation-state, with a political unity of its own, which raised in a new form the question of the autonomy of the temporal order and its processes, that is, the question of libertas regalis. Because neither side had fully grasped the problem, the result of the controversy was an impasse. The contemporary controversy, in which the term libertas regalis has dissolved into the term libertas civilis, likewise reached an impasse on the Continent in the nineteenth century, again because neither side had fully grasped the problem. However, if it be true, as I think it is, that the problem has now been grasped (at least by the Church-no state that considers itself The One Power ruling All That Is has yet seen the problem), an impasse is no longer necessary. And the avoidance of an impasse, in a world that is full of them, is no mean achievement.

\section{THE CONFESSIONAL STATE}

What I have said does not, of course, go all the way toward the solution of the contemporary controversy - the seeming clash between libertas ecclesiastica and libertas civilis. The reason is obvious. In the so-called democratic concept of civil liberty, the idea of religious liberty has the same amplitude as the idea of civil liberty itself. As it declares the civic equality of all citizens before the law, so it likewise declares the civic equality of all churches and religious professions before the law. As it recognizes equal liberty for the public expression of any political idea, even though it be contrary to the common civic beliefs, so it recognizes equal liberty for the public expression of any religious idea, again even though it be contrary to common religious beliefs. And this concept of libertas civilis does seem to be in conflict with the concept of libertas ecclesiastica as realized in the so-called confessional state, wherein the freedom of the Church, expressed in the concept of "the religion of the state," is represented as entailing what Pius XI called "the logical and juridical consequences of such a situation of constitutional law," ${ }_{125}$ namely, some manner of restriction on the propaganda of other religious groups.

${ }^{15}$ Letter to Card. Gasparri, May 30, 1929, Lo Grasso, Ecclesia et Status, n. 831. 
There rises therefore the whole problem of the so-called confessional state, and the status it possesses in Catholic teaching. That it has a status is certainly true; but what status it has is another question, around which there is controversy among Catholics. The Spanish bishops recently undertook to complain: "It is astonishing that there are Catholics outside of Spain who attack Catholic unity in itself and hold doctrines which are completely incompatible both with the Syllabus of Pius IX and with the encyclical Libertas of Leo XIII." And they express the wish "that Catholics of all lands would keep before their minds (the) principle of Leo XIII" concerning religious toleration. For their own part: "We Catholic Spaniards will avoid criticising our brethren, who are in a minority in other states and nations, because they shelter themselves under the banner of liberty. However, that will never lead us to grant, as a thesis, the same rights to error as to truth. And let Catholics of all countries, if they wish truly to be Catholics, if they wish to be faithful to papal teachings-let them be on their guard against ridiculing, as intransigent and backward, the Catholics of Spain or of any other country which has the great fortune of preserving Catholic unity, because of their defense of this Catholic unity." 126

This is indeed a sharp rebuke and a rude lesson in orthodoxy. However, if I may say it under all respect for their Excellencies, the sharpness of the rebuke is not matched by clarity and completeness in the statement of an issue that concerns not merely the Spanish nation but the universal Church; similarly the lesson in orthodoxy in regard of the Catholic "thesis" on Church-state relationships is (again, sit venia verbo) just a bit too rude, in the Latin sense of the word. Those who know something of the results reached in medieval times or even in the sixteenth century by sheerly dialectical interpretation of the Decretum Gratiani will not antecedently have confidence in the results that may be reached by application of the same method to the Syllabus or to the Leonine corpus.

Moreover, the question is not Catholic unity - the desirability of its maintenance; the question is, quali auxilio? And that question has an important political dimension. Again, the question is not whether

1a Instruccion de la Conferencia de Metropolitanos Espańoles, May 28, 1948, Signo, 19 de Junio, 1948, p. 3. 
error has the same rights as truth. Even supposing that this question has any meaning in the political order (in which one does not find "error" or "truth" somehow disembodied, but only citizens or institutions who are uttering what they conceive to be true, even though it may be error), the answer to it, whether affirmative or negative, does not constitute an operative political principle. (Incidentally, the question itself was dragged into this whole matter, not by Catholics but by rationalist and secularist philosophers, as a polemical red herring of purest hue.) Moreover, the question is not whether the total politicoreligious organization of contemporary Spain is an apt means, defensible from a political and religious standpoint, for saving or restoring Catholic unity in Spain and the national values of Hispanidad. Finally, the question is not whether, in a "constitutional situation" wherein is enshrined the concept of "religion of the state," there follow certain "logical and juridical consequences" with regard to the suppression of other forms of belief and worship.

For the theologian, the basic question concerns that constitutional situation itself - is it or is it not the theologically necessary, permanently valid, unalterably ideal realization of Catholic principles on Church-state relationships, in such wise that any constitutional situation which deviates from it can be the object only of "toleration," not of approval in principle - a concession to the exigences of an "hypothesis," prompted by expediency, and not the embodiment of a "thesis," warranted by theological and political doctrine. In other words, the question is whether the concept of libertas ecclesiastica by intrinsic exigence requires political embodiment in the concept of "the religion of the state," with the "logical and juridical consequences" that have historically followed from that concept.

Surely the answer must be no. Moreover, I should give the answer a prospective, not a retrospective sense; it is not a judgment on past or present constitutional situations, but simply a theological answer to the question itself, as put. Moreover, I think that an affirmative answer to the question would somehow imply a denial or neglect of that "vital law of continual adaptation" which is the law of the Church's thought and action; it would imply, in contradiction of Pius XII, that the Church somehow refuses to follow "the providential path of history and circumstances." Actually, it was along that path, and in obedience 
to that law, that the Church came to the idea that the "freedom of the Church" meant being "the religion of the state." But this idea is certainly not the end of the road, beyond which lies only aberration. Surely I do not have to believe-what would again be in contradiction of Pius XII-that the Church has suddenly become "petrified in a given moment of history," the post-Reformation era, and has "closed herself to all further progress."

Boniface VIII unconsciously attempted a petrifaction of the medieval respublica christiana; he could conceive of no other "thesis" on Church-state relationships than the one Innocent IV had elaborated. We know the results, that were symbolized by the tragedy of Anagni. They were wrought by an implacably dynamic political development that, for all its extravagance, bore in its depths an intention of nature. With this development the Church then coped, and in terms of it (the nation-state), amid conditions created by absolutist political theory and practice, aggravated by religious upheaval, there came the new thing, the confessional state, embodying the constitutional idea of "the religion of the state" (not, I need hardly say, a medieval idea). In its historical realizations it was, in Sturzo's exact judgment, "formalistic and equivocal," ${ }_{127}$ especially in its post-Revolution revivals. It initially represented a desperate attempt to rescue out of the wreckage of political and religious disruption some national fragments of religious unity and political order. Later it represented an attempt to heal, by the so-called Union of Throne and Altar, the cleavage between the religious and the political order that had opened at the Renaissance and been widened by the Reformation.

However, as Sturzo says, "In this embarrassing union of Church and State a connecting link was wanting to bind the peoples to the absolute and religious power. The Church was now no mediatrix between the people and power, nor did the state mediate between people and Church." ${ }_{128}$ The essence of the medieval union coutumière was wanting; for the spiritual substance of society had been dissipated by the indifferentism of the cultured classes and the apostasy of the working-class. The "union" of Church and state existed only at the top, expressed in juridical forms that were as much the occasion of

m Op. cil., p. 404.

as Loc. cit. 
jurisdictional disputes as the instrument of dynamic harmony and cooperation. This fact (which was, I think, somewhat analogous to the inner weakening of the empire at the time of Philip the Fair) rendered the confessional state unable to cope with the new implacable dynamic political movement unleashed by the Revolution - the rise of the "citizen." The movement was destructive, of course, as the rise of the nation-state had been; but it too bore in its depths an intention of nature. It was a far more profound and beneficent intention than was inherent in the nation-state; for it was the fundamental intention, present beneath the welter of false ideology that almost concealed it, to situate the human person at the center of the whole social order, and make him the temporal element of the dyarchy whereby society is to be ruled.

This intention of nature has, I said, been recognized and welcomed by the Church; and this fact has moved the problem of Church-state relations into a new phase. (Actually, today the problem is not "Church and state," but Church and society; or perhaps more exactly, in the formula used before, "the freedom of the Church and the freedom of the citizen.") The problem in its new phase is governed by the new dyarchy, Church and Christian citizen, which has behind it all the warrant in theological and political principle, and in papal approval, necessary to legitimate the erection on it of a genuine Catholic thesis. In an essay already grown too long this construction can hardly be undertaken. However, I can perhaps at least indicate the problem confronting the Catholic theologian.

The first problem is that of determining and clarifying the exact status in Catholic doctrine possessed by the concept of the confessional state. An analysis of sources in Reformation and post-Reformation times would, of course, be necessary. However, primary in view would be the doctrine of Leo XIII. Here I shall say only that one must distinguish in it three aspects - a doctrinal, a polemic, and what I should call an historical aspect. On the doctrinal level his work was the restatement of the Gelasian thesis in itself and in its root and finality; this was his fundamental contribution. On the polemic level his work was the refutation of the naturalistic and rationalistic bases of Liberalism - or state secularism, as it would be better called; his premises here were a metaphysic of liberty and an ethic of the state, by 
whose elaboration he gave a more profound and philosophical statement to the positions of Gregory XVI and Pius IX. Thirdly, there was his approval of the concept of the confessional state, contained in his treatment of the relations between the "Catholic state" and the various religions within its boundaries. In the light of this tripartite construction of his total teaching the problem is, to which of the two other aspects of his thought is this approval of the confessional state related? Is it somehow a necessary prolongation of his restatement of the Gelasian thesis? Or is it more properly part of his reaction to the "Liberal state" of naturalistic and rationalistic theory - to the laicized state - which was at the time installed in the traditionally Catholic nations of Europe? This is the general judgment that has to be made.

For my part, I think that the concept of the confessional state in Leo XIII is more properly related to the polemic than to the doctrinal aspects of his teaching; this is why I called it, for want of a better name, the "historical" part of his work, wishing to imply that historical circumstance had much to do with its fashioning. My main reason for this judgment may be briefly put. The dyarchy historically characteristic of the confessional state - the Union of Throne and Altar, in its various forms - did lead in the logic of all its premises to a constitutional situation embodying the concept of "the religion of the state," with consequent legal restrictions on other religious beliefs. This constitutional situation was inherent in the starting point and essential premise of the confessional state, as laid down, for instance, in the statement of the Spanish bishops already cited - the religious unity of a nation. On the political side, the premise of the confessional state was a tradition of centralized governmental power; actually, it is this fact that generates, the particular dyarchy, Throne and Altar. On the premises of the confessional state therefore it was conceived to be politically logical that there should devolve on the Throne the function of preserving, by the use of governmental power, the unity of the religion at whose Altar the whole nation knelt. Moreover, this function had the character of a political function by reason of the fact that religious unity was conceived to be an essential aspect of that national unity of which the state was the political form. It was this total constitutional situation which Continental Liberalism attacked, in the name of a state secularism, a laicization of government. And it was natural that Leo XIII's rejection of Liberalism should lead to 
an approval of the historic constitutional situations that it attacked.

However, the intimately theological question is whether the constitutional situation characterized by the concept, "the religion of the state," is in the logic of Leo XIII's restatement of the Gelasian thesis (as carried on and completed by Pius XI and Pius XII), with its new concrete dyarchy, Church and Christian citizen. I think not. The starting point is different-not a national religious unity to be preserved by the action of the Throne in union with the Altar, but the spiritual unity of the whole man in his concrete and historical reality, to be preserved by the action of the citizen, that is, by his freedom so to direct the processes of government and the institutions of society that they will not disrupt but solidify his spiritual unity. The political premise here is not a centralization of government; nor is it even that more predominantly ethical and, as it were, formal concept of the state that appears in Leo XIII's polemic against Liberalism. It is the more dynamic and juridical concept of the state- the state as action and as rooted in the human person-that appears in Pius XI and Pius XII (whose whole political thinking, it may be noted, is orientated towards the construction of a new order, and not towards the defense of an old one). Finally, in the pure perspectives of the traditional Gelasian theory, as now developed, the problem of nationalism does not enter.

I say therefore that in these perspectives and in the logic of these premises one need not, and indeed cannot, go on to the constitutional situation characteristic of the confessional state. The new constitutional situation that flowers out of the new dyarchy is not one that translates the concept, "freedom of the Church," into the concept, "the religion of the state." The freedom of the Church is, of course, always an exigence of the dyarchy itself, however constituted; so too is the freedom of the "state" (whether it be emperor, king, or citizen who is regarded as the concrete bearer of the temporal power). However, in the logic of the new Gelasian dyarchy is simply that freedom of the Church, in its essential content, to which Pius XI adverted in his encyclical to the Mexican bishops. There is a twofold element. First, there is "a just freedom of action" for the Church herself-a positive freedom to deploy in full her spiritual power towards the preservation of her own unity and the development of the supernatural 
life in each of her members. Secondly, there is "for the faithful the enjoyment of the right to live in civil society according to the precepts of reason and conscience," that is, the right to be a citizen and a Christian - and one whole man, in whom prevails a harmony of his dual obedience. ${ }^{129}$

This is the pregnant right, that derives from the dyarchy whereby human life is ruled, and that in turn resolves the dyarchy into unityinto a finalistic unity, which is the oneness of man as Christian and citizen. However, this resolution is effected only if this pregnant right is delivered (to continue the metaphor) of the whole set of empowerments contained in the concept of "the freedom of the citizen." They are the necessary, rational, constitutional means whereby civil society in its structure and processes may become such that a man can live in it according to the dictates of reason and conscience. The delivery to the human persons who are members of the Church of these rights, which are now politically necessary to support the freedom of the Church, is only possible, and can only be effected, because they are citizens of a state in which these rights are contained in the concept of the freedom of the citizen. This concept of the freedom of the citizen is of autonomous origin, like the concept of the state itself. And the rights it contains are therefore by definition available for all the citizens of the state; it is only on this title that the members of the Church may claim them. Consequently in their enjoyment all citizens are equal as citizens.

I should say that this is in outline the constitutional situation towards which the orientations in contemporary Catholic thought on Church and state are themselves orientated. It is a situation which would recognize that "freedom of the Church" which is inherently demanded by the Gelasian thesis in its present development. However, it would not embody the concept, "religion of the state," with the consequences in the way of civil intolerance that have been considered to follow logically and juridically in the confessional state. Consequently, between "the freedom of the Church" as envisaged in the contemporary orientations of Catholic thought, and "the freedom of the citizen" as envisaged in contemporary political realizations, there is, and need be, no conflict. This is the essential point that I wanted briefly to suggest.

wencyclical to the Mexican Bishops, Firmissimam Constantiam, March 28, 1937, Lo Grasso, op. cil., n. 850. 